\title{
The cost of financial flexibility: Evidence from share repurchases
}

\author{
Alice A. Bonaimé ${ }^{\mathrm{a}, *}$ \\ Kristine W. Hankins ${ }^{b}$ \\ Bradford D. Jordan ${ }^{b}$ \\ Journal of Corporate Finance, forthcoming
}

February 2016

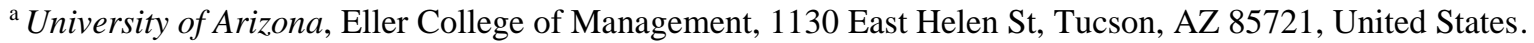

${ }^{\mathrm{b}}$ University of Kentucky, Gatton College of Business and Economics, 550 S Limestone, Lexington, KY 40506 , United States.

* Contact author.

E-mail addresses: alicebonaime@email.arizona.edu (A.A. Bonaimé), kristine.hankins@uky.edu (K.W. Hankins), brad.jordan@uky.edu (B.D. Jordan).

We thank Heitor Almeida, Leonce Bargeron, Matt Billett, Murillo Campello, Harry DeAngelo, Mike Ehrhardt, Mike Faulkender, Jon Garfinkel, Jarrad Harford, Nicole Jenkins, Shawn Mobbs, Jacob Oded, Joshua Pierce, Shawn Thomas, and seminar participants at the Mid-Atlantic Research Conference, the Paul Woolley Centre for the Study of Capital Market Dysfunctionality Conference, Texas A\&M University, the Universidad de los Andes, the University of Kansas, and the University of Tennessee for helpful comments and suggestions. Any errors remain our own. 


\title{
The cost of financial flexibility: Evidence from share repurchases
}

\begin{abstract}
Over the last two decades, share repurchases have emerged as the dominant payout channel, offering a more flexible means of returning excess cash to investors. However, little is known about the costs associated with payout-related financial flexibility. Using a unique identification strategy, we document a significant cost. We find that actual repurchase investments underperform hypothetical investments that mechanically smooth repurchase dollars through time by approximately two percentage points per year on average. This cost of financial flexibility is correlated with earnings management, managerial entrenchment, and less institutional monitoring.
\end{abstract}

Keywords: Financial flexibility, payout policy, share repurchase, earnings management, corporate governance

JEL Classification: G30, G34, G35 


\section{It would have been wiser to wait. We are sorry.}

James Dimon, CEO of J.P. Morgan Chase, apologizing for $\$ 8$ billion in buybacks done earlier in the year. (October 13, 2011)

\section{Introduction}

Poor market timing by J.P. Morgan Chase notwithstanding, the supposed advantages of repurchases as a means of distributing cash to shareholders are well known among academics and managers. Surveyed financial executives prefer repurchases to dividends because of their flexibility. Executives claim to "use this flexibility in an attempt to time the market by accelerating repurchases when they believe their stock price is low" as well as vary payout based on the availability of good projects (Brav, Graham, Harvey, and Michaely (2005)). While it is almost surely true that managers value this flexibility, it is less clear that they reliably add value using it.

Payout policy — which encompasses the form, amount, and timing of distributions to shareholders - is a core corporate finance issue. Unlike dividends, which are sticky, repurchases provide managers flexibility with respect to the amount and timing of payouts. Ideally, managers use this flexibility to benefit shareholders. However, the existing literature raises questions on whether payout flexibility has costs as well. Jensen (1986) highlights the potential agency conflict, noting "conflicts of interest between shareholders and managers over payout policies are especially severe when the organization generates substantial free cash flow.” Barclay and Smith (1988) explore "a previously unrecognized cost associated with regular open-market repurchases" and assert that the presence of informed insiders affects bid-ask spreads and the cost of capital. More recently, Brown, Liang, and Weisbenner (2007) study the 2003 dividend tax cut to understand the choice of payout and note that "consistent with a standard agency theory perspective that, rather than operating the firm solely in the best interests of shareholders ... managers are inclined to also 
incorporate their own financial incentives in corporate decisions." Given these issues, our goal is to quantify the costs associated with giving managers flexibility with respect to payout.

We study actual share repurchases using a sample of 5,498 firms that repurchased stock during at least one quarter between 1984 and 2010. To evaluate the cost of repurchase-related financial flexibility, we compare the average annualized rate of return on a firm's repurchased stock over varying windows to the rate of return the firm would have earned had it made regular, identically sized (i.e., dividend-like) repurchases. In other words, we estimate the difference in returns on the firm's actual repurchase strategy and an alternative repurchase strategy that assumes equal distributions across time, i.e., no flexibility. Using the actual dollar amount spent by a firm and assuming that buying occurs at the end of each quarter over the life of the firm in our sample, we find the average return on repurchase spending would rise significantly if firms had smoothed their buybacks more evenly. The average annualized rate of return earned by firms on repurchased stock is 7.66 percent, but this average return rises significantly to 9.64 percent if these same firms instead had smoothed repurchase spending evenly across time. The approximately two percentage point difference represents the cost of varying repurchases across quarters as opposed to holding repurchase dollars constant each quarter. Our naïve, mechanical repurchase strategy outperforms actual repurchases if we smooth repurchases over shorter time windows (one, two, three, and four years instead of the entire sample period), but the longer the time window, the more our smoothed strategy outperforms the actual repurchase strategy. We replicate this analysis using actual buyback prices, which are available in quarterly filings starting in 2004. Though our sample is reduced, we document similar patterns.

We address a variety of potential concerns. We ensure the availability of cash on hand to execute our proposed smoothed repurchase strategy by smoothing repurchase spending forward in 
time such that actual repurchase dollars were spent during or before the smoothed repurchase quarter. We explore how the motive for repurchasing relates to the costs and benefits of repurchase flexibility. However, we find that even the subsample of firms that explicitly state undervaluation as a motive for repurchasing could have made a significantly better investment by spreading out their repurchases more evenly over longer smoothing periods. Further, we allow for optimal within-quarter repurchase timing by assuming that all repurchases occur at the minimum daily closing price each quarter and continue to identify a significant cost to repurchase flexibility. In fact, assuming firms can optimally time repurchases within the quarter increases our cost estimate to over 5.5 percentage points per year.

We rule out the argument that our smoothing strategy is not executable from a legal perspective by examining repurchase timing after the adoption of Securities and Exchange Commission (SEC) Rule 10b5-1 in 2000, when firms in our sample could have legally set up a regular trading schedule that closely resembles our proposed smoothed repurchase strategy. We address the concern that suspending repurchases may be rational ex ante by examining only completed repurchase plans. Further, we show that firms with low completion rates-firms that may be more deliberate or strategic in their repurchase program-also could benefit from our smoothed repurchase strategy. Finally, our results withstand a battery of additional robustness tests, which include: (1) excluding Dutch auctions, tender offers, and accelerated share repurchases, which provide less flexibility than open market share repurchases; (2) stopping our sample period prior to the recent financial crisis; (3) conditioning on only the most liquid firms, whose prices are least sensitive to repurchase buying pressure; (4) calculating repurchases net of stock issues; and (5) using size and book-to-market benchmark-adjusted returns. In all cases, we identify a positive and significant cost to repurchase-related financial flexibility. 
We conclude by examining the cross-sectional determinants of the cost of repurchase flexibility, measured as the difference between the actual repurchase return and that of the smoothed (no flexibility) repurchase strategy. This approach sheds light on the frictions preventing firms from reducing this cost. We find that the cost of repurchase flexibility is greater when there is a desire to manage EPS, when institutional ownership is low, when institutional investors are selling into the repurchase, and when managers are more entrenched. These results are consistent with firms with high agency costs incurring greater costs associated with repurchase flexibility.

Our findings contribute to the literature along multiple dimensions. We contribute to the dividend substitution literature by highlighting a significant cost to payout flexibility. We add to the literature on whether managers reliably exploit inside information through repurchasing at attractive values. One strand of this literature identifies positive and significant long-run abnormal returns following open market share repurchase announcements (e.g., Ikenberry, Lakonishok, and Vermaelen (1995), Peyer and Vermaelen (2009)), often interpreted as evidence of repurchase timing skill. A second stream of literature focuses on the execution of share repurchase programs and provides evidence that firms can time repurchases well over relatively short periods of time (e.g., Brockman and Chung (2001), Cook, Krigman, and Leach (2004), and Dittmar and Field (2015)). Conversely, Dittmar and Dittmar (2008) examine repurchases at the macroeconomic level and conclude that repurchases increase following GDP growth and are thus highly pro-cyclical. We conclude that if firms exploit inside information through repurchase transactions, the information must be short-term (less than one year) rather than long-term in nature. We contribute to the literature on monitoring and corporate governance by showing that the cost of financial flexibility is significantly correlated with incentives to manage earnings, institutional investor 
selling, and managerial entrenchment. Finally, we add to the literature quantifying the costs and benefits to financial flexibility, as in Rapp, Schmid, and Urban (2014).

\section{Previous evidence on repurchase flexibility}

A well-developed literature on share repurchases focuses on why firms repurchase stock (e.g., Dittmar (2000)). Firms repurchase for a variety of reasons: to reduce agency costs by distributing excess cash to shareholders (Jensen (1986)), to combat the dilutive effect of stock option exercise (Kahle (2002)), and to fend off unwanted takeover bids (Billett and Xue (2007)), to name a few. Additionally, managers often cite financial flexibility as an important reason for choosing repurchases over more sticky dividends (Brav, Graham, Harvey, and Michaely (2005)). Maintaining more discretion over distributions to shareholders clearly allows managers to quickly respond to cash flow and investment shocks.

Financial flexibility also may add value if managers are able to successfully exploit inside information in their repurchase transactions by purchasing shares at prices below their true value. Several recent papers use the more detailed disclosure of U.S. repurchase transactions available after 2003 to test whether firms consistently repurchase at below-average prices. When comparing actual repurchase prices to average stock prices during the same month or quarter, results are generally consistent with managers exhibiting repurchase timing skills, particularly within small firms (e.g., Ben-Rephael, Oded, and Wohl (2014)) and firms that repurchase less frequently and whose insiders are simultaneously purchasing in their own accounts (Dittmar and Field (2015)). ${ }^{1}$

\footnotetext{
${ }^{1}$ Other studies have also examined whether firms exploit insider information to repurchase at low prices. For example, Chan, Ikenberry, and Lee (2007) find that managers are, in fact, good timers relative to benchmark control firms. Cook, Krigman, and Leach (2004) analyze voluntary repurchase trading data on 64 NYSE and Nasdaq firms during 1993 and 1994 and find that NYSE firms are more price sensitive because they tend to buy back shares after stock price declines. However, neither group of firms consistently anticipated price increases. Brockman and Chung (2001) use data from Hong Kong to compare actual repurchase trades to bootstrapped repurchase trades that occur during the same year and with the same frequency, but that differ on timing. They find that actual repurchase costs are generally lower than those incurred by bootstrapped repurchases on different days and interpret their results as evidence of managerial timing ability.
} 
While it is informative to examine the timing of repurchases over short horizons, firms execute repurchase programs over periods spanning multiple quarters and many firms, especially in recent years, could be characterized as "frequent repurchasers," i.e., firms with multiple repurchase authorizations over a relatively short period of time (Jagannathan and Stephens (2003)). In fact, many firms authorize new repurchase programs immediately upon completion of a prior program (Bargeron, Bonaimé, and Thomas (2016)). Therefore, examining longer-term relationships between repurchases and prices is an important addition to the discussion of the added value of repurchases, in part for the simple reason that across-quarter variation in stock prices is greater than within-quarter variation, particularly over longer time periods. Examining longer horizons also is interesting because it speaks to the nature of the private information, if any, that managers are using to inform their repurchase timing decisions. We find that, on average, managers do not use the financial flexibility associated with repurchases to exploit long-term private information.

All in all, our results are most consistent with Dittmar and Dittmar (2008), who study macroeconomic patterns or "waves" in stock issuances and repurchases, and Kahle (2002), who links repurchase activity to employee stock option exercise. Though stock issues and repurchases are arguably opposite transactions, Dittmar and Dittmar (2008) find that issues and repurchases are 90 percent correlated, and they attribute this correlation to the business cycle. They conclude that "market timing is unlikely to be driving patterns in corporate financing events." Bolton, Chen, and Wang (2013) attribute this pro-cyclical repurchasing to an evolving precautionary demand for cash. Our evidence contributes to this discussion by quantifying a potential cost of payout flexibility. 


\section{Data and summary statistics}

We begin with all U.S. firms in the merged Compustat/CRSP universe that repurchase stock during at least one quarter over the period 1984 - 2010. A firm enters our sample the first time it repurchases at least 0.1 percent of its shares outstanding during a quarter, which we consider a "non-trivial" repurchase. ${ }^{2}$ We then express dollar repurchases as a percentage of shares outstanding by dividing by the firm's market capitalization measured at the end of the prior quarter. We also require the firm to have a CRSP share code 10 or 11 and a beginning-of-quarter stock price greater than $\$ 5$. To avoid any survivor or look-ahead biases, once we include a firm in our sample, it remains in our sample until the company delists or we reach the end of 2010. Our final sample consists of 5,498 firms and 198,693 firm-quarter observations.

We calculate the dollar value spent on share repurchases as the Compustat quarterly purchase of common and preferred stock from the cash flow statement (adjusted for the fact that this variable is cumulative) minus any decrease in reported balance sheet preferred stock. Banyi, Dyl, and Kahle (2008) identify this measure as the most accurate proxy for actual common shares repurchased, especially for firms with high levels of employee stock option exercise.

Table 1 presents quarterly summary statistics on the magnitude and frequency of share repurchases. We first compute statistics at the firm-quarter level. The dollar value spent on repurchases is highly skewed: On average firms repurchase $\$ 20.24$ million per quarter, but the median $\left(90^{\text {th }}\right.$ percentile) dollar value spent on repurchases is zero ( $\$ 16.70$ million). Conditional on

\footnotetext{
${ }^{2}$ An argument could be made that a firm should enter our sample after its first repurchase announcement instead of after its first actual repurchase. For example, a firm could announce a repurchase, wait a year, then begin repurchasing and is arguably exercising payout flexibility by delaying the actual repurchase. However, Stephens and Weisbach (1998) show that by the first quarter after the announcement two-thirds of firms repurchase at least 5 percent of their announced amount, which would trigger our 0.1 percent repurchase indicator even for a relatively small repurchase announcement of 2 percent of shares outstanding. In addition, failing to include the time period between the first announcement and the actual repurchase would only bias our findings if the stock price tended to decrease between the announcement and actual repurchase; yet, the repurchase literature finds the opposite.
} 
repurchases being greater than zero, the average (median) firm repurchases $\$ 66.11$ million $(\$ 5.08$ million) per quarter. Repurchases expressed as a percentage of shares outstanding are also skewed, but to a lesser extent. On average firms in our sample repurchase one half of one percent per quarter, and the median $\left(90^{\text {th }}\right.$ percentile) percent of shares outstanding repurchased is zero (1.4 percent). Conditional on positive repurchases, the average (median) firm buys back 1.75 percent (0.84 percent) of shares outstanding.

Firms in our sample repurchase non-trivial amounts of stock during 30.6 percent of firm quarters. The last row of Table 1 presents statistics on firm-level means of our non-trivial repurchase indicator variable. In other words, we equally weight each firm in our sample by computing the average of our repurchase indicator by firm and then calculate summary statistics. The average (median) firm repurchases non-trivial amounts of stock during 24.3 percent (28.3 percent) of quarters. A firm at the $10^{\text {th }}$ percentile $\left(90^{\text {th }}\right.$ percentile) repurchases stock during 7.5 percent (68.3 percent) of quarters.

\section{The cost of financial flexibility: Motivating evidence}

We begin our empirical analysis by examining firm-level repurchasing activity. For each firm, we simply calculate average log stock prices and valuation ratios across all of its repurchasing and non-repurchasing quarters. We then calculate the within-firm differences in log prices and valuations between repurchasing and non-repurchasing quarters. We next average the averages and the differences, thereby giving equal weight to each firm (as opposed to each firm-quarter). For the $t$-tests, we use only the average difference for each firm in a univariate test. ${ }^{3}$

As shown in Table 2, we find evidence consistent with repurchase activity being correlated with high stock prices. The average, split-adjusted $(\log )$ closing price in non-repurchasing quarters

\footnotetext{
${ }^{3}$ A standard independent, two-sample $t$-test is poorly specified because repurchases have significant common variation.
} 
is 2.44 compared to 2.56 in repurchasing quarters, so (based on the means) log prices are 4.9 percent higher in repurchasing quarters, a substantial premium. Note that our sample construction process biases us against finding this result because we first observe a company in a quarter in which it does a repurchase. Given the tendency of (split-adjusted) stock prices to rise through time, we might expect to see the non-repurchasing quarters have at least somewhat higher stock prices, on average. Thus, our 4.9 percent premium, which implies a premium of approximately 12.7 percent in raw stock price, is probably conservative.

We find similar premiums if we use the minimum closing price, which might represent a "best case scenario" repurchase price; the volume-weighted closing price, which proxies for the average price at which the stock was traded that quarter; or a randomly chosen within-quarter closing price. No matter which price we use, firms repurchase more when stock prices are higher. Further, using the minimum closing price precludes our results from being driven by any positive abnormal announcement returns if repurchasing activity occurs more frequently in announcement quarters.

To directly address the undervaluation question, we look at book-to-market (B/M) and sales-to-price (S/P) ratios. ${ }^{4}$ Regardless of which ratio we evaluate, we see that firms buy back stock when valuations are less favorable. For example, the mean B/M (using beginning-of-quarter values) is 0.72 during non-repurchasing quarters, compared to 0.66 in repurchasing quarters. Similarly, for $\mathrm{S} / \mathrm{P}$, the means are 0.55 versus 0.45 , again based on beginning-of-quarter values.

\footnotetext{
${ }^{4}$ We do not examine earnings to price (E/P) ratios because 21.5 percent (20.9 percent) of our firm quarters have negative earnings before (after) extraordinary items. Higher earnings or lower prices should be associated with higher valuation ratios, which holds true when earnings are positive. However, with negative earnings, higher (closer to zero) earnings are associated with higher (less negative) E/P ratios, but lower prices lead to lower (more negative) E/P ratios. Mixing the two together can thus paint a misleading picture. The same issue exists for book-to-market ratios, but it is much less severe because only 2.3 percent of our firm-quarters have a negative book value.
} 
For robustness, we extend our comparison of repurchasing and non-repurchasing quarters. As noted, detailed repurchase price information is only available for the later part of the sample. The Securities and Exchange Commission modified Rule 10b-18 in December of 2003 to require firms to report both the total number of shares repurchased and the average price paid per share in all quarterly and annual filings on or after March 15, 2004. To use the actual repurchase prices, we reconstruct our sample using only the time period 2004 to 2010 . We delete firms with zero repurchases between 2004 and 2010 and delete firms with a stock price less than $\$ 5$ when they enter the sample. The total number of shares repurchased and average repurchase price per share are reported in Compustat Quarterly. To ensure the accuracy of our repurchase measures, we delete firms with a reported quarterly average repurchase price outside of quarterly max and min, as these are likely data errors or cases where the firm repurchased shares in conjunction with employee stock option plans. ${ }^{5}$ We also remove firms with stock splits between 2004 and 2010 because whether or not the reported prices are pre- or post-split is ambiguous. Panel B presents the comparison using this post-2004 sample of actual repurchase prices. Panel C replicates the analysis by years within the full sample to verify the pattern is robust across the life-cycle of the firm. Both Panels B and C indicate that repurchasing quarters are associated with higher per-share prices. Overall, Table 2 is consistent with repurchase motives being correlated with periods of high stock prices, which prompts us to further examine the relationship between repurchases and stock prices.

\footnotetext{
${ }^{5}$ For example, in the fiscal quarter ending December 31, 2010, Cabot Corp. reported an average repurchase price of $\$ 24.48$ even though its quarterly low was $\$ 32.19$. The corresponding 10 -Q reveals that many of the repurchased shares were unvested restricted stock from terminated employees purchased at the employee's original purchase price for the stock, which was $\$ 9.61$ on average.
} 


\section{Estimating the cost of repurchase-related financial flexibility}

To estimate the cost of repurchase-related financial flexibility, we consider a simple experiment. We calculate the rate of return on each firm's investment in its own stock (as of the end of 2010 or until the firm delists). The rate of return is the internal rate of return on the investment such that the future value of the repurchases equals the terminal value, often referred to as a "dollar-weighted average return." (Appendix A provides a full description of our return measures.) Then, for each firm, we consider an alternative strategy of spending the same total dollar amount repurchasing stock, but, instead of using the actual repurchase quarters and amounts, we spread the total dollar amount evenly over varying lengths of time, initially assuming that purchases are made on the last day of each quarter. ${ }^{6}$ In effect, we ask what would have happened had firms followed a naïve strategy of making evenly spaced, evenly sized repurchases through time. We refer to these evenly spaced repurchases as "smoothed" repurchases.

\subsection{The return on repurchase spending}

In Panel A of Table 3, we calculate the dollar value spent on share repurchases as the Compustat quarterly purchase of common and preferred stock from the cash flow statement (adjusted for the fact that this variable is cumulative) minus any decrease in reported balance sheet preferred stock. We assume that repurchases occur at the end of each quarter. We then compute average annualized returns on repurchases, thereby removing the effect of firm size. The average firm earned an annual return of 7.66 percent with its actual repurchases, assuming a holding period equal to the sample life of the firm. We next examine how firms would have done had they spread their repurchases smoothly over shorter periods of time. To do this, we take each firm's actual

\footnotetext{
${ }^{6}$ Note that the assumption that purchases are made on the last day of the quarter is not critical because it applies to both the actual and the hypothetical smoothed repurchase prices. Therefore, because we focus entirely on the difference in the performance of the two strategies, any bias from using any particular day within a quarter as the benchmark starting point will tend to net out.
} 
repurchases over every period of $N$ years in length $(N=1,2,3,4)$ and convert them to evenly spaced (and sized) amounts (we shorten the last such period as needed). Smoothing occurs in event time. ${ }^{7}$ Thus, for $N=1$, smoothing occurs over 4 quarters. In this case, firms would have earned an average of 8.14 percent, an economically and statistically significant improvement. Moving to two or more years produces a steady improvement: At the 4-year window, the return from the smoothed repurchase strategy is 1.75 percent per year greater. Finally, if we assume equally spaced and sized purchases over the sample life of the firm, the return rises to 9.64 percent, a gain of almost 2 percentage points per year. This increase in returns represents the cost of varying repurchases as opposed to holding them constant throughout time.

While Panel A uses the end of quarter price to calculate returns for both the actual and smoothed strategies, Panel B replicates this analysis using the actual post-2004 reported repurchase prices. A challenge presented by the new data is that firms obviously do not report an average repurchase price in quarters during which they are not repurchasing. We are thus forced to make assumptions about repurchase prices for our smoothed repurchase strategy. Actual repurchases occur throughout the quarter. Hence, to align the timing of actual and hypothetical smoothed repurchases as closely as possible, we assume that repurchases occur in the middle of the quarter for our smoothed strategy. In other words, if a quarter has 61 trading days, we use the closing price from day 31 as the repurchase price.

When we replicate our main findings for the post-2004 time period using actual reported repurchase prices and amounts, we find that the benefits to smoothing begin after two years and range from a 1.43 percentage point gain in returns to repurchases for two-year smoothing to an impressive 3.61 percentage point gain for smoothing over the sample lifetime. The difference in

\footnotetext{
${ }^{7}$ If a firm enters the sample during quarter 1 , then time period 1 corresponds to event quarters $1-4$, time period 2 to event quarters 5-8, etc. Two-year, three-year, and four-year smoothing are for 8, 12, and 16 quarters.
} 
returns to actual and smoothed repurchases is statistically significant over the longer (three-year, four-year, and full sample) time periods.

\subsection{Do firms have cash available for smoothed repurchases?}

A concern with our original measure is that firms with longer repurchase programs may not have the cash on hand to smooth repurchases evenly through time, particularly if repurchase activity is not clustered near the announcement. We therefore ensure the availability of cash by smoothing repurchase spending forward in time. For example, for a one-year time period, smoothed repurchases in a quarter equal the sum of repurchases over the past four quarters, divided by four (in other words, a four-quarter moving average). Thus, actual repurchase dollars were spent during or before the smoothed repurchase quarter.

The results using our forward smoothed repurchases are reported in Table 4. The differences in annualized returns on smoothed and actual repurchases remain statistically and economically significant. For our full sample, forward smoothing repurchases over one year implies a 1.71 percentage point increase in annual returns, and forward smoothing over longer time periods is even more beneficial. In fact, smoothing repurchases forward over four years leads to a 3.72 percentage point difference in annualized returns. For our post-2004 sample, the benefits to smoothing also are greater when we smooth repurchases forward in time: The difference in annualized returns to actual and smoothed repurchases ranges from 3.93 to 9.77 percentage points, and all differences are significant at the one percent level.

\subsection{Controlling for repurchase motives}

Undervaluation or "timing the market" is only one of many reasons to repurchase stock. If firms repurchase to fend off takeovers or for other potentially value maximizing reasons, we might not expect to observe firms repurchasing when prices are low. To examine whether alternative 
repurchase motives - motives other than undervaluation - drive our finding that firms' actual repurchase investments underperform a naïve smoothed repurchase strategy, we limit our sample to firms that explicitly state undervaluation as a motive for repurchasing. Beginning in 1994, the Securities Data Corporation (SDC) Repurchases database reports "purpose codes," which correspond to the motive for the share repurchase. ${ }^{8}$ We verify the accuracy of the purpose codes through a Factiva search and identify 943 firms that explicitly stated undervaluation as a motive for a share repurchase over the longer 1984 - 2010 period.

Consistent with the existing evidence of skill in the short term, smoothing repurchases doesn't improve returns over a short horizon. These results are consistent with repurchase flexibility not imposing significant costs within this subsample of firms over relatively short time periods. However, these firms would have earned significantly higher returns by smoothing repurchases in the longer run. Panel A of Table 5 illustrates that returns on repurchases smoothed over three (four) years were 1.03 percentage points (1.24 percentage points) greater than returns on actual repurchases. Further, smoothing over the entire sample period yields returns 2.40 percentage points greater. These results suggest that even the group of firms that publicly assert that they are making a good investment in their stock could have made a better investment by just mechanically spreading out their repurchases evenly.

\footnotetext{
${ }^{8}$ The 11 purpose codes correspond to "General corporate purpose," "Enhance shareholder value," "Employee benefit plan," "Stock option plan," "Undervalued," "Offset dilution effects," "Acquisition purposes," "Conversion of warrants," "Prevent a takeover," "Conversion of preferred stock," and "Conversion of options." Each announcement can correspond to up to three purpose codes, though announcements are rarely associated with more than two codes. Most announcements have only one code, and half of announcements are associated "General corporate purposes." We supplement this data by verifying all announcements after 1994 available in Factiva, by adding several categories, and by allowing announcements to be associated with as many codes as possible. Our final groups include "Undervaluation," "General corporate purposes," "Extension of prior plan," "Earnings per share," "Enhance shareholder value," "Acquisition/Prevent takeover," "Employee stock option plan," "Strong cash position," "Good investment," "Confidence," and "Other." The most frequently observed code is "General corporate purposes," followed by "Enhance shareholder value," "Employee stock option plan," and "Undervaluation."
} 
In Panel B of Table 5, we restrict our sample to the 263 firms that explicitly stated undervaluation as a motive for repurchasing after 2004 and use the more detailed repurchase price information. Again, we find no cost to repurchase-related financial flexibility in the one-year smoothing window, but a significant benefit to smoothing exists over longer time periods (two years and beyond). The difference in annualized returns to actual and smoothed repurchases is economically meaningful and ranges from 1.35 for two-year smoothing to 5.05 for full sample smoothing.

\subsection{Robustness of returns on repurchase investment}

\subsubsection{Can a smoothed repurchase strategy be executed?}

Stock buybacks emerged as a viable payout channel in 1982 when the Securities and Exchange Commission (SEC) began granting safe harbor to firms repurchasing their own stock. The SEC approved Rule 10b-18, protecting firms from liability for stock price manipulation as long as share repurchases are executed in accordance with the SEC's manner, timing, price, and volume conditions. ${ }^{9}$ While the volume condition would discourage lumpy repurchasing and would bias us against finding a difference in returns on actual and smoothed repurchases, these and other SEC regulations, such as blackout periods around mergers and acquisitions, may prevent firms from optimally repurchasing stock and may render our smoothed repurchase strategy difficult to execute.

However, on August 15, 2000, the SEC adopted a new Rule 10b5-1 that allows firms to establish a trading schedule or trading rules in advance and hence repurchase stock during times

\footnotetext{
${ }^{9}$ To summarize briefly, firms should use a single broker or dealer, should refrain from trading at opening or during the last half hour of trading, should not buy at a price higher than the highest independently published bid, and may purchase no more than 25 percent of the average daily trading volume in the prior four calendar weeks. (See http://www.sec.gov/rules/final/33-8335.htm.)
} 
when they otherwise could not. ${ }^{10}$ Therefore, after the year 2000, firms in our sample could have legally set up regular trading schedules that mimic our proposed smoothed repurchase strategy.

Panel A of Table 6 presents the returns on actual repurchases conducted between 2001 and 2010 (after the adoption of SEC Rule 10b5-1) and compares them to returns on smoothed repurchases over the same time period. The average firm earned an annual return of 7.02 percent with its actual repurchases between 2001 and 2010. If these firms had spread their repurchases smoothly over one or two years, they would have earned an average of 7.46 percent or 8.60 percent, respectively, both statistically and economically larger than the return on actual repurchases. And returns to smoothed repurchases are greater for longer smoothing periods: Using a three-year window, a four-year window, and the full sample period, returns increase to 9.53 percent, 9.28 percent, and 10.13 percent, respectively, all representing statistically and economically significant increases in returns of over two percentage points per year. Thus, we can conclude that even during a time period when firms could have automated a smoothed repurchase program, the average firm still chose to maintain financial flexibility and further incurred a significant cost in doing so.

\subsubsection{Open market repurchase plan completion rates: Were managers rational ex ante?}

Anecdotally, firms frequently cite a need to "conserve cash" when they suspend a repurchase program. For example, in October 2008, Dow-component Alcoa announced it was suspending its repurchase program. Klaus Kleinfeld, Alcoa's chief executive, said the reason was

\footnotetext{
${ }^{10} \mathrm{~A}$ firm can adopt a written trading plan at a time when it is unaware of material, nonpublic information or delegate trading decisions to another entity not in possession of material, nonpublic information. These trades are not covered under safe harbor, but meeting the following criteria sets forth an affirmative defense: (1) the firm entered into a written trading agreement before obtaining material, nonpublic information; (2) the written contract either specifies specific amounts, dates, and prices or a specific trading algorithm, or the firm completely outsources trading and does not exert influence on the execution of the trades; and (3) the repurchase is part of a prior plan and has not been altered or hedged. Modifications to Rule 10b5-1 plans are permitted as long as the firm is not in possession of material, nonpublic information at the time of the modification and meets the above criteria required at the inception of the plan. See http://www.sec.gov/rules/final/33-7881.htm.
} 
"to conserve cash and maximize profitability through very adverse economic conditions." ${ }^{11}$ In broader terms, aggregate repurchases reached a peak in our sample in 2007 before declining sharply in 2009. Of the firms in our sample, 63.0 percent repurchased stock during at least one quarter of 2007, but only 39.4 percent repurchased any shares in 2009, a decline of 37.5 percent.

Such repurchase suspensions may look irrational ex post even though the behavior was rational ex ante. Suspending repurchase programs to conserve cash might be quite rational. Under some possible future states of the world, a firm's cash flows become insufficient to fund valuable investments and capital markets become illiquid. Preserving liquidity against such an event might be very much in the interests of shareholders. However, a suspension may look like bad market timing ex post, at least on the surface.

We investigate the concern that our results are purely driven by repurchase plans being suspended by conditioning on repurchase plan completion. Specifically, we use open market repurchase announcements from the Securities Data Corporation (SDC) Mergers and Acquisitions database and calculate completion rates based on our proxy for quarterly share repurchases. We consider a repurchase plan completed if the firm repurchases at least 90 percent of the announced amount, either in terms of dollar value or number of shares outstanding, within three or four years of the announcement. For completed plans, we compare the annualized rate of return on actual repurchases (based on Compustat values) over the three or four years following the repurchase announcement to the same value of actual repurchases smoothed over the same period. Panel B of Table 6 presents these results. Under either definition of plan completion, firms would have increased the annualized rates of returns on their repurchase investment by smoothing repurchases. Hence, our results are not driven by suspended repurchase programs.

\footnotetext{
11 “Alcoa third-quarter net down; cutting back spending." October 7, 2008. Reuters.
} 
On the other hand, firms that exercise the option not to complete a repurchase program are interesting in and of themselves since they may be more deliberate or skilled in executing their repurchases. We therefore examine whether firms with low completion rates could benefit from our smoothing strategy. We categorize a firm as having a low completion rate if it repurchased less than 25 percent of the announced amount. Panel C of Table 6 presents these results. Firms with low completion rates would have increased the annualized rates of returns on their repurchase investment by smoothing repurchases.

5.4.3 Minimum closing price: What if managers perfectly time repurchases in the short run?

As we have noted, there is evidence that some firms are able to time repurchases well in the short run (e.g., Ben-Rephael, Oded, and Wohl (2014), De Cesari, Espenlaub, Khurshed, and Simkovic (2012), and Dittmar and Field (2015)). To examine how short-term timing ability affects the benefits of smoothing repurchases over longer time periods, we compare returns to actual repurchase investments to smoothed repurchase investments, assuming that all repurchases occur at the minimum daily closing price each quarter. In other words, we allow for optimal, perfect foresight within-quarter repurchase timing over the full sample and then examine whether firms could have earned a higher rate of return on repurchase investments if they had smoothed their repurchase dollars more evenly across quarters. Due to the large within-quarter variation in stock prices in some firms, we are concerned about the effect of outliers on our returns calculations. For example, the median actual return to repurchases is 9.28 percent which is comparable to prior 
returns calculation, but the mean is 55.34 percent, implying extreme skewness. To mitigate the effect of outliers, we winsorize at the $1^{\text {st }}$ and $99^{\text {th }}$ percentile. $^{12}$

Panel D of Table 6 presents the returns to actual and smoothed repurchases, assuming that repurchases occur at the minimum daily closing price each quarter. As expected, all returns increase if firms can perfectly time repurchases within the quarter, but, most importantly, the cost of repurchase-related financial flexibility is highly significant in all cases. Returns increase 2.21 percentage points annually when repurchases are smoothed over one year and 3.79 percentage points when repurchases are smoothed over two years. The benefit of smoothing repurchases over three or four years is approximately 4.5 percentage points, and the benefit of smoothing over the sample lifetime of the firm is 5.6 percentage points. All of the differences in means are highly statistically significant and are greater than the differences when repurchases are presumed to occur at the quarterly closing price. These results are consistent with payout flexibility having a cost even if firms are able to optimally time repurchases in the short run.

\subsubsection{Additional robustness tests}

Panel E segments firms by stated motives. The motives over which we have data are: undervaluation, earnings per share (EPS), acquisition, and employee stock options. A firm falls into a category if it stated the motive at the time of any share repurchase announcement made during our sample period. The categories are not mutually exclusive. We find that firms in all categories could significantly benefit from our smoothed repurchase strategy over the full sample period but this varies widely by stated motivation. The categories with the greatest return

\footnotetext{
${ }^{12}$ Though mean returns are very large in all cases where we assume that repurchasing occurs at the minimum stock price and do not winsorize, the difference in the means of the actual and smoothed repurchases are positive (ranging from 2.29 to 5.57 percent) and significant in every case.
} 
differential are "undervaluation" and "EPS." "Employee stock option" and "acquisition" firms reap lower or no benefits depending on the smoothing window.

In a final set of robustness tests, we ensure that our results hold when we (1) exclude firms that announced a Dutch auction, tender offer, or accelerated share repurchase over the sample period, (2) exclude the 2008-2010 financial crisis period, (3) condition on the most liquid firms based on Amihud (2002) illiquidity, (4) calculate repurchases net of stock issuances, and (5) use size and book-to-market benchmark-adjusted rates of returns to repurchases (see Appendices B.1 and B.2). We also verify that our main conclusions hold across various subsample splits on the length of time in the sample, firm size quintiles, book-to-market quintiles, lagged returns quintiles, cash quintiles, and delisting status (see Appendix B.3).

\section{Factors associated with repurchase value}

In this section, we examine some attributes of firms related to the costs and benefits of financial flexibility with respect to their repurchase activity. We measure Repurchase Value as the difference between the actual annualized returns on share repurchases and the annualized returns from a four-year smoothed repurchase strategy, based on event time and beginning when the firm enters the sample. The terminal value is calculated at the end of each smoothing period. Negative (positive) values of Repurchase Value indicate that returns on actual repurchases underperform (outperform) a smoothed repurchasing strategy and imply high cost (low cost) repurchases. In Table 7, we examine the determinants of Repurchase Value in an OLS regression setting with lagged firm control variables, Fama-French 49 industry fixed effects, and year fixed effects. The standard errors are robust and adjusted for clustering at the firm level.

We first consider the role of earnings management since managers may use repurchases to inflate earnings per share (Hribar, Jenkins, and Johnson (2006)). We identify firms with an 
incentive to manage earnings per share due to a desire to meet analyst forecast expectations or potential dilution concerns. Earnings Management 1: Analysts is a dummy variable equaling one if the company met or beat the mean analyst forecast but would have missed in the absence of the repurchase. We calculate the without-repurchase EPS using the 'As-If l' EPS measure of Cheng, Harford, and Zheng (2015) and compare it to the IBES mean analyst estimate to identify firms that would have missed earnings estimates. Likewise, we compare the actual EPS to the mean analyst estimate to identify firms that met or beat analysts' forecasts. Earnings Management 2: Dilution is an indicator variable equaling one if the firm repurchased in any quarter of the event window when the number of shares would have increased otherwise. ${ }^{13}$ As shown in Table 7, both earnings management variables are consistently negative and statistically significant. Firms that use repurchases to meet analyst EPS forecasts or offset potential dilution incur a greater cost to financial flexibility.

Ideally, monitoring should offset activities that decrease shareholder value. If institutional investors provide monitoring (Hartzell and Starks (2003)), then we expect repurchase timing to be positively correlated with institutional ownership in the firm. Indeed, firms with greater levels of Institutional Ownership \%, the percentage of shares owned by institutional investors, are better repurchase timers. But institutional ownership could also proxy for investor sophistication (e.g., Bartov, Radhakrishnan, and Krinsky (2000), DeLisle, Morscheck, and Nofsinger (2014)), and sophisticated investors may be aware of the wealth transfer that accompanies suboptimal repurchases. If sophisticated institutional investors can identify repurchases occurring at inflated stock prices, then they will attempt to sell their shares to the firm at the time of the repurchase.

\footnotetext{
${ }^{13}$ For robustness, we alternatively define Earnings Management 2: Dilution as the number of quarters where the firm repurchased and the number of shares outstanding would have increased in the absence of the repurchase. The results are qualitatively similar.
} 
To capture simultaneous repurchasing and institutional selling, we define Institutional Exit as the percent of quarters within the event window where the firm has significant repurchase activity (repurchases greater than $1 \%$ of common shares outstanding) as well as significant declines in institutional ownership (decreases in institutional ownership of greater than $1 \%$ of common shares outstanding). Then, to understand which institutions sell into a repurchase, we limit our sample to post-1994 when we have blockholder data and set Lost Blockholder equal to one if the firm lost a blockholder over the one-year window. Blockholders are shareholders owning more than $5 \%$ of the firm who have filed form $13 \mathrm{G}$ with the SEC over the past twelve months. In isolation, losing a blockholder generally is not correlated with repurchase timing. However, when we interact Lost Blockholder with Institutional Exit, we see that losing a potential monitor exacerbates the negative effect of institutional selling. These results are consistent with Huang and Thakor (2013), who find that firms repurchase more when investor-management disagreement is high, especially if the selling investor owns a large block. They argue that disagreement-induced repurchases can be conducted above and beyond the firm's current valuation consideration.

We further explore the role of governance by examining firms where we have the Bebchuk, Cohen, and Farrell (2009) entrenchment index. Bebchuk et al. find that six of the twenty-four Investor Responsibility Research Center provisions are correlated with firm value and use these to construct an entrenchment score, the $E$ Index. We explore whether managerial entrenchment, and the associated weak market for corporate control, is related to suboptimal repurchase timing. After creating an indicator variable for high levels of entrenchment (an E Index greater than or equal to 4, a score above both the mean and median), we document that weaker shareholder rights (i.e., high $E$ Index firms) are consistently associated with worse repurchase timing. 
Malmendier and Tate (2005) show that overconfidence can distort corporate investment, so we test whether overconfidence is associated with the cost of financial flexibility. We proxy for overconfidence with CEO purchasing of firm stock in his or her private account, using Thomson Financial data on the total value of CEO buying over the current year to create an indicator variable. While CEO buying may reflect private information, it also is a deliberate decision not to pursue diversification. Our proxy for overconfidence is negative but not statistically significant. This finding may indicate a noisy or weak proxy. However, in unreported results, we test two additional overconfidence proxies (the value of unexercised but exercisable options scaled by total compensation and scaled by lagged market capitalization) and fail to find evidence that managerial overconfidence is a determinant of the cost of repurchase-related financial flexibility.

In addition, we examine the relationship between the stated motivations for a repurchase and repurchase timing skill. Motivations are created using the "purpose codes" from the SDC Repurchases database and are linked based on whether the motivation was announced within the event window. While firms announce a variety of different motivations, we focus on four of the more common and potentially most value relevant classifications: Earnings per Share (EPS), Employee Stock Options (ESOPs), Undervaluation (UV) and Acquisition (Acq). Since these motivations may induce collinearity, we regress the motivations against Repurchase Value with and without firm control variables. Firms that explicitly state a repurchase is being conducted to manage earnings per share (EPS) exhibit worse timing when the potentially collinear control variables are excluded. More interesting, undervaluation is uniformly correlated with worse longterm repurchase value. These results provide additional support for the earlier Table 5 findings.

Lastly, we examine a number of firm characteristics that prior literature has found to be relevant to repurchasing. Harford (1999) finds that cash-rich firms are more likely to engage in 
value-decreasing acquisitions. Cash is cash and cash equivalents, scaled by total assets, and Cash Flow is the sum of income before extraordinary items and depreciation and amortization, scaled by total assets. We study whether firm size affects repurchase timing as in Ben-Rephael, Oded, and Wohl (2014), who find that small firms are able to repurchase at attractive prices within the same month. Firm size is measured as the natural log of market capitalization. Capital structure can also influence repurchase decisions because repurchases decrease a firm's equity and thus increase its leverage ratio. Dittmar (2000) finds that repurchasing firms have lower leverage ratios than non-repurchasing firms and that firms repurchase stock to alter their leverage ratio. If the perceived benefits to adjusting capital structure outweigh the cost of repurchasing at elevated stock prices, then firms with low leverage may be worse repurchase timers. Leverage, defined as total liabilities scaled by total assets, proxies for capital structure. $R \& D$, defined as research and development expense scaled by total assets, and Cap Ex, defined as capital expenditures scaled by total assets measured at the end of the prior quarter, proxy for alternative investment options. Cash, Cash Flow, Firm Size, Leverage, Cap Ex, and $R \& D$ are measured at the end of the prior quarter and are winsorized at the $1^{\text {st }}$ and $99^{\text {th }}$ percentile. Dividends is an indicator variable equal to one if the firm paid a dividend in the prior year. Finally, since market timing may motivate buybacks, we proxy for undervaluation with $B / M$, the book value of common equity divided by market capitalization at the end of the prior quarter, and Negative $B / M$, a dummy equal to one if $B / M$ is negative. Our results indicate that Repurchase Value is not consistently related to these lagged firm controls. Given the absence of predictive power, we do not report those coefficients in Table 7 for conciseness. 


\section{Summary and conclusions}

Given their inside information and experience, one may expect managers to use payoutrelated financial flexibility to add value through strategic repurchase timing, buying when share prices are low and refraining from buying otherwise. Yet, we find that a repurchase strategy with little or no flexibility would result in lower repurchase prices on average. This cost of financial flexibility is correlated with a variety of what can be defined broadly as corporate governance issues: active earnings management, loss of monitors, and entrenched managers.

Thus, when it comes to repurchases, there appears to be a cost to payout flexibility. Even if some managers are able to time the market in the short run, our results raise questions about whether payout discretion routinely and consistently enhances long-term shareholder value. Other studies have shown that managers have some ability to time repurchases over relatively short horizons, and we do not contradict those findings. Instead, our contribution is to identify a significant cost associated with varying payouts over longer time periods (one year or more). Interestingly, even when allowing for perfect within-quarter repurchase timing (i.e., repurchasing at the minimum closing price with the quarter), we continue to document a significant cost associated with repurchase-related financial flexibility.

In addition, our findings may help explain the rise of so-called accelerated repurchase programs (Bargeron, Kulchania, and Thomas (2011)) and 10b5-1 programs, both of which outsource repurchase timing to an investment bank. Further, the role of institutional selling into lower quality repurchases raises interesting issues about the tradeoffs between long-term and shortterm investors. 


\section{References}

Amihud, Yakov. 2002. Illiquidity and stock returns: Cross-section and time-series effects. Journal of Financial Markets 5, 31-56.

Banyi, Monika L., Edward A. Dyl, and Kathleen E. Kahle. 2008. Errors in estimating share repurchases. Journal of Corporate Finance 14, 460-474.

Barclay, Michael J., and Clifford W. Smith. 1988. Corporate payout policy: Cash dividends versus open-market repurchases. Journal of Financial Economics 22, 61-82.

Bargeron, Leonce, Alice Bonaimé, and Shawn Thomas. 2016. The timing and source of long-run returns following repurchases. Journal of Financial and Quantitative Analysis, forthcoming.

Bargeron, Leonce, Manoj Kulchania, and Shawn Thomas. 2011. Accelerated share repurchases. Journal of Financial Economics 101, 69-89.

Bartov, Eli, Suresh Radhakrishnan, and Itzhak Krinsky. 2000. Investor sophistication and patterns in stock returns after earnings announcements. Accounting Review 75, 43-63.

Bebchuk, Lucian, Alma Cohen, and Allen Farrell. 2009. What matters in corporate governance? Review of Financial Studies 22, 783-827.

Ben-Rephael, Azi, Jacob Oded, and Avi Wohl. 2014. Do firms buy their stock at bargain prices? Evidence from actual stock repurchase disclosures. Review of Finance 18, 1299-1340.

Billett, Matthew T., and Hui Xue. 2007. The takeover deterrent effect of open market share repurchases. Journal of Finance 62, 1827-1850.

Bolton, Patrick, Hui Chen, and Neng Wang. 2013. Market timing, investment, and risk management. Journal of Financial Economics 109, 40-62.

Brav, Alon, John R. Graham, Campbell R. Harvey, and Roni Michaely. 2005. Payout policy in the $21^{\text {st }}$ century. Journal of Financial Economics 77, 483-527.

Brockman, Paul, and Dennis Y. Chung. 2001. Managerial timing and corporate liquidity: Evidence from actual share repurchases. Journal of Financial Economics 61, 417-448.

Brown, Jeffrey R., Nellie Liang, and Scott Weisbenner. 2007. Executive financial incentives and payout policy: firm responses to the 2003 dividend tax cut. Journal of Finance 62, 1935-1965.

Chan, Konan, David L. Ikenberry, and Inmoo Lee. 2007. Do managers time the market? Evidence from open-market share repurchases. Journal of Banking and Finance 31, 2673-2694.

Cheng, Yingmei, Jarrad Harford, and Tianming (Tim) Zheng. 2015. Bonus-driven repurchases, Journal of Financial and Quantitative Analysis 50, 447-475. 
Cook, Douglas O., Laurie Krigman, and J. Chris Leach. 2004. On the timing and execution of open market repurchases. Review of Financial Studies 17, 463-498.

De Cesari, Amedeo, Susanne Espenlaub, Arif Khurshed, and Michael Simkovic. 2012. The effects of ownership and stock liquidity on the timing of repurchase transactions. Journal of Corporate Finance 18, 1023-1050.

DeLisle, Jared, J.D. Morscheck, and John R. Nofsinger. 2014. Share repurchases and institutional supply. Journal of Corporate Finance 27, 216-230.

Dittmar, Amy K. 2000. Why do firms repurchase stock? Journal of Business 73, 331-355.

Dittmar, Amy K., and Robert F. Dittmar. 2008. The timing of financing decisions: An examination of the correlation in financing waves. Journal of Financial Economics 90, 59-83.

Dittmar, Amy K., and Laura C. Field. 2015. Can managers time the market? Evidence using repurchase price data. Journal of Financial Economics 115, 261-282.

Harford, Jarrad. 1999. Corporate cash reserves and acquisitions. Journal of Finance 54, 19691997.

Hartzell, Jay C., and Laura T. Starks. 2003. Institutional investors and executive compensation. Journal of Finance 58, 2351-2374.

Hribar, Paul, Nicole Throne Jenkins, and W. Bruce Johnson. 2006. Stock repurchases as an earnings management device. Journal of Accounting and Economics 41, 3-27.

Huang, Sheng, and Anjan V. Thakor. 2013. Investor heterogeneity, investor-management disagreement and share repurchases. Review of Financial Studies 26, 2453-2491.

Ikenberry, David L., Josef Lakonishok, and Theo Vermaelen. 1995. Market underreactions to open market share repurchases. Journal of Financial Economics 39, 181-208.

Jagannathan, Murali, and Clifford Stephens. 2003. Motives for multiple open-market repurchase programs. Financial Management 32, 71-91.

Jensen, Michael C. 1986. Agency costs of free cash flow, corporate finance, and takeovers. American Economic Review 76, 323-329.

Kahle, Kathleen M. 2002. When a buyback isn't a buyback: Open market repurchases and employee options. Journal of Financial Economics 63, 235-261.

Malmendier, Ulrike, and Geoffrey Tate. 2005. CEO overconfidence and corporate investment. Journal of Finance 60, 2661-2700. 
Peyer, Urs, and Theo Vermaelen. 2009. The nature and persistence of buyback anomalies. Review of Financial Studies 22, 1693-1745.

Rapp, Marc Steffen, Thomas Schmid, and Daniel Urban. 2014. The value of financial flexibility and corporate financial policy. Journal of Corporate Finance 29, 288-302.

Stephens, Clifford, and Michael Weisbach. 1998. Actual share reacquisitions in open-market repurchase programs. Journal of Finance 53, 313-333. 


\section{Table 1: Share repurchase magnitudes and frequencies}

This table presents quarterly summary statistics on share repurchases and share repurchase indicators for all U.S. firms in the merged Compustat/CRSP universe that repurchase stock during at least one quarter over the period 1984 - 2010. A firm enters our sample the first time it repurchases at least 0.1 percent of its shares outstanding during a quarter and remains in our sample until December 2010 or until it delists. We also require the firm to have a CRSP share code 10 or 11 and a beginning-of-quarter stock price greater than \$5. Our final sample consists of 5,498 firms and 198,693 firm-quarter observations. Rows (1) and (2) present summary statistics at the firm-quarter level on repurchases expressed in millions of dollars, unconditional and conditional on positive repurchases, respectively. Rows (3) and (4) present summary statistics at the firm-quarter level on repurchases expressed as a percentage of shares outstanding, unconditional and conditional on positive repurchases, respectively. Row (5) presents summary statistics at the firm-quarter level for our repurchase indicator variable, which equals one when repurchases are greater than 0.1 percent of shares outstanding. Row (6) presents summary statistics on firm-level means of our repurchase indicator variable.

\begin{tabular}{llcccccc}
\hline & & & Standard & \multicolumn{3}{c}{ Percentiles } \\
\cline { 6 - 8 } & & \# Obs & Mean & deviation & $10^{\text {th }}$ & $50^{\text {th }}$ & $90^{\text {th }}$ \\
\hline (1) & Repurchases (millions \$) & 198,693 & 20.242 & 172.771 & 0 & 0 & 16.700 \\
(2) & Repurchases (millions \$) if $>$ \$0 & 60,840 & 66.106 & 307.332 & 0.231 & 5.075 & 124.556 \\
& & & & & & & \\
(3) & Repurchase (\% shares outstanding) & 198,693 & 0.536 & 2.470 & 0 & 0 & 1.414 \\
(4) & Repurchase (\% shares outstanding) if $>0 \%$ & 60,840 & 1.750 & 4.219 & 0.186 & 0.841 & 3.578 \\
& & & & & & & \\
(5) & Repurchase $>$ 0.1\% indicator & 198,693 & 0.306 & 0.461 & 0 & 0 & 1 \\
(6) & Firm-level mean: Repurchase $>0.1 \%$ indicator & 5,498 & 0.243 & 0.190 & 0.075 & 0.283 & 0.683 \\
\hline
\end{tabular}




\section{Table 2: The timing of share repurchases}

This table presents the within-firm averages and differences in split-adjusted stock prices and valuation ratios in repurchasing quarters and non-repurchasing quarters (Diff). Panel A summarizes the results for firms in our sample between 1984 and 2010, Panel B presents the results for the post-2004 sample, and Panel C presents the comparison across different groups based on the time in the full sample. Firms must have prices or valuation ratios in at least one repurchasing quarter and at least one non-repurchasing quarter to be included in the calculation. Repurchasing quarters are quarters during which the firm repurchased at least 0.1 percent of shares outstanding. Average closing price is the natural log of the mean daily closing price. Minimum closing price is the natural log of the minimum daily closing price. Volume-weighted average closing price is the natural log of the average quarterly daily closing price, weighted by daily trading volume. $\mathrm{B} / \mathrm{M}$ is the book value of common equity divided by market capitalization. S/P is net sales per share divided by stock price. Variables with subscript $t(t-l)$ are measured at the end of the current (prior) quarter. All valuation ratios are winsorized at the $1^{\text {st }}$ and $99^{\text {th }}$ percentiles.

Panel A: Full Sample

\begin{tabular}{lccccc}
\hline Valuation measure & \# Obs & $\begin{array}{c}\text { Non-repurchasing } \\
\text { quarters }\end{array}$ & $\begin{array}{c}\text { Repurchasing } \\
\text { quarters }\end{array}$ & $\begin{array}{c}\text { Difference } \\
\text { in means }\end{array}$ & $t$-stat \\
\hline Average closing price & 5,331 & 2.438 & 2.555 & 0.117 & 15.86 \\
Minimum closing price & 5,331 & 2.251 & 2.382 & 0.131 & 16.71 \\
Volume-weighted closing price & 5,331 & 2.441 & 2.551 & 0.110 & 15.80 \\
Random closing price & 5,331 & 2.431 & 2.548 & 0.118 & 14.92 \\
$\mathrm{~B} / \mathrm{M}_{t-1}$ & 5,323 & 0.722 & 0.656 & -0.066 & -15.07 \\
$\mathrm{~B} / \mathrm{M}_{t}$ & 5,295 & 0.716 & 0.686 & -0.030 & -6.38 \\
$\mathrm{~S} / \mathrm{P}_{t-1}$ & 4,787 & 0.554 & 0.449 & -0.105 & -20.23 \\
$\mathrm{~S} / \mathrm{P}_{t}$ & 4,762 & 0.567 & 0.486 & -0.082 & -14.54 \\
\hline
\end{tabular}

Panel B: Post-2004 sample

\begin{tabular}{lccccc}
\hline Valuation measure & \# Obs & $\begin{array}{c}\text { Non-repurchasing } \\
\text { quarters }\end{array}$ & $\begin{array}{c}\text { Repurchasing quarters } \\
\text { (Actual average price) }\end{array}$ & $\begin{array}{c}\text { Difference } \\
\text { in means }\end{array}$ & $t$-stat \\
\hline Average closing price & 1,402 & 2.830 & & 0.170 & 14.48 \\
Minimum closing price & 1,402 & 2.662 & & 0.338 & 25.61 \\
Volume-weighted closing price & 1,402 & 2.829 & 3.006 & 0.171 & 14.42 \\
Random closing price & 1,402 & 2.822 & & 0.178 & 14.91 \\
\hline
\end{tabular}

\section{Panel C: Time in Sample}

\begin{tabular}{lcccccccccc}
\hline Years in sample: & \multicolumn{2}{c}{$0-5$ (Short) } & \multicolumn{2}{c}{6 -10 } & \multicolumn{2}{c}{11 -15 } & \multicolumn{2}{c}{16 -20 } & \multicolumn{2}{c}{$>$ (Long) } \\
\cline { 2 - 11 } Valuation measure & Diff & $t$-stat & Diff & $t$-stat & Diff & $t$-stat & Diff & $t$-stat & Diff & $t$-stat \\
\hline Average closing price & 0.047 & 7.09 & 0.016 & 1.85 & 0.055 & 5.23 & 0.05 & 3.92 & 0.123 & 7.35 \\
Minimum closing price & 0.052 & 7.36 & 0.022 & 2.46 & 0.056 & 4.97 & 0.049 & 3.65 & 0.135 & 7.11 \\
Volume-wgt closing price & 0.039 & 5.95 & 0.012 & 1.46 & 0.051 & 4.89 & 0.047 & 3.63 & 0.119 & 7.14 \\
Random closing price & 0.047 & 7.01 & 0.015 & 1.78 & 0.054 & 5.07 & 0.049 & 3.81 & 0.125 & 7.10 \\
\hline
\end{tabular}




\section{Table 3: Return on repurchase investment}

This table presents summary statistics and difference in means tests on the annualized rate of return (in \%) on actual repurchase investments versus "smoothed" repurchases. Smoothed repurchases are generated by averaging actual repurchases over one-, two-, three-, or four-year periods, or the entire sample life of the firm, as indicated. Panel A presents results for 5,498 firms in our sample between 1984 and 2010. Panel B uses actual repurchase prices reported by 1,549 firms in quarterly filings between 2004 and 2010. Appendix A provides a full description of our returns measures.

\section{Panel A: Full sample}

\begin{tabular}{lccccc}
\hline & \multicolumn{3}{c}{ Summary statistics } & \multicolumn{2}{c}{$\begin{array}{c}\text { Difference in annualized return } \\
\text { on investment (in \%) }\end{array}$} \\
\cline { 2 - 6 } & Mean & Median & $\begin{array}{c}\text { Standard } \\
\text { deviation }\end{array}$ & $\begin{array}{c}\text { Mean - Actual } \\
\text { repurchases mean }\end{array}$ & $t$-test \\
\hline Actual repurchases & 7.658 & 5.048 & 59.565 & & \\
Repurchase average - 1 year & 8.136 & 5.129 & 60.542 & 0.478 & 2.22 \\
Repurchase average - 2 years & 8.838 & 5.865 & 60.915 & 1.180 & 5.34 \\
Repurchase average - 3 years & 9.225 & 6.436 & 60.866 & 1.567 & 6.79 \\
Repurchase average - 4 years & 9.404 & 6.893 & 60.957 & 1.746 & 7.43 \\
Sample lifetime & 9.639 & 7.994 & 61.252 & 1.981 & 8.00 \\
\hline
\end{tabular}

Panel B: Post-2004 sample

\begin{tabular}{lccccc}
\hline & \multicolumn{3}{c}{ Summary statistics } & \multicolumn{2}{c}{$\begin{array}{c}\text { Difference in annualized return } \\
\text { on investment (in \%) }\end{array}$} \\
\cline { 2 - 6 } & Mean & Median & $\begin{array}{c}\text { Standard } \\
\text { deviation }\end{array}$ & $\begin{array}{c}\text { Mean - Actual } \\
\text { repurchases mean }\end{array}$ & $t$-test \\
\hline Actual repurchases & 9.114 & 2.871 & 76.962 & & \\
Repurchase average - 1 year & 8.909 & 3.282 & 56.606 & -0.205 & -0.20 \\
Repurchase average - 2 years & 10.540 & 4.606 & 56.071 & 1.426 & 1.40 \\
Repurchase average - 3 years & 12.042 & 6.360 & 55.649 & 2.928 & 2.86 \\
Repurchase average - 4 years & 11.527 & 5.763 & 55.783 & 2.413 & 2.35 \\
Sample lifetime & 12.721 & 7.278 & 55.526 & 3.607 & 3.48 \\
\hline
\end{tabular}




\section{Table 4: Forward-looking repurchase measure}

This table presents summary statistics and difference in means tests on the annualized rate of return (in \%) on actual repurchase investments versus "smoothed" repurchases. Smoothed repurchases are generated by averaging actual repurchases forward in time. Panel A presents results for 5,498 firms in our sample between 1984 and 2010. Panel B uses actual repurchase prices reported by 1,549 firms in quarterly filings between 2004 and 2010. Appendix A provides a full description of our returns measures.

\section{Panel A: Full sample}

\begin{tabular}{lccccc}
\hline & \multicolumn{3}{c}{ Summary statistics } & \multicolumn{2}{c}{$\begin{array}{c}\text { Difference in annualized return } \\
\text { on investment (in \%) }\end{array}$} \\
\cline { 2 - 6 } & Mean & Median & $\begin{array}{c}\text { Standard } \\
\text { deviation }\end{array}$ & $\begin{array}{c}\text { Mean - Actual } \\
\text { repurchases mean }\end{array}$ & $t$-test \\
\hline Actual repurchases & 7.658 & 5.048 & 59.565 & & \\
Repurchase average - 1 year & 9.366 & 5.704 & 62.380 & 1.708 & 10.00 \\
Repurchase average - 2 years & 10.573 & 6.939 & 63.015 & 2.915 & 14.40 \\
Repurchase average - 3 years & 11.117 & 7.622 & 63.267 & 3.459 & 16.16 \\
Repurchase average - 4 years & 11.374 & 8.054 & 63.408 & 3.716 & 16.96 \\
\hline
\end{tabular}

\section{Panel B: Post-2004 sample}

\begin{tabular}{lccccc}
\hline & \multicolumn{3}{c}{ Summary statistics } & \multicolumn{2}{c}{$\begin{array}{c}\text { Difference in annualized return } \\
\text { on investment (in \%) }\end{array}$} \\
\cline { 2 - 6 } & Mean & Median & $\begin{array}{c}\text { Standard } \\
\text { deviation }\end{array}$ & $\begin{array}{c}\text { Mean - Actual } \\
\text { repurchases mean }\end{array}$ & $t$-test \\
\hline Actual repurchases & 9.114 & 2.871 & 76.962 & & \\
Repurchase average - 1 year & 13.041 & 4.448 & 73.642 & 3.927 & 4.11 \\
Repurchase average - 2 years & 16.236 & 7.812 & 74.042 & 7.122 & 7.15 \\
Repurchase average - 3 years & 17.886 & 9.914 & 74.129 & 8.772 & 8.67 \\
Repurchase average - 4 years & 18.882 & 11.248 & 74.157 & 9.768 & 9.58 \\
\hline
\end{tabular}




\section{Table 5: Firms with stated motive of undervaluation}

This table presents summary statistics and difference in means tests on the annualized rate of return (in \%) on actual repurchase investments versus "smoothed" repurchases for the subsample of firms that stated "undervaluation," "enhance shareholder value," or "good investment" as a motive for a share repurchase. Smoothed repurchases are generated by averaging actual repurchases over one-, two-, three-, or four-year periods, or the entire sample life of the firm, as indicated. Panel A presents results for 943 firms that stated undervaluation as a repurchase motive between 1984 and 2010. Panel B uses actual repurchase prices in quarterly filings between 2004 and 2010 reported by 263 firms that stated undervaluation as a motive between 2004 and 2010. Appendix A provides a full description of our returns measures.

\section{Panel A: Full sample}

\begin{tabular}{lccccc}
\hline & \multicolumn{3}{c}{ Summary statistics } & \multicolumn{2}{c}{$\begin{array}{c}\text { Difference in annualized return } \\
\text { on investment (in \%) }\end{array}$} \\
\cline { 2 - 6 } & Mean & Median & $\begin{array}{c}\text { Standard } \\
\text { deviation }\end{array}$ & $\begin{array}{c}\text { Mean - Actual } \\
\text { repurchases mean }\end{array}$ & $t$-test \\
\hline Actual repurchases & 2.173 & 4.159 & 25.799 & & \\
Repurchase average - 1 year & 2.022 & 4.258 & 24.697 & -0.151 & -1.83 \\
Repurchase average - 2 years & 2.680 & 4.623 & 25.153 & 0.507 & 1.13 \\
Repurchase average - 3 years & 3.199 & 5.374 & 24.538 & 1.026 & 2.50 \\
Repurchase average - 4 years & 3.410 & 5.546 & 24.588 & 1.237 & 3.08 \\
Sample lifetime & 4.568 & 6.976 & 24.587 & 2.395 & 5.69 \\
\hline
\end{tabular}

Panel B: Post-2004 sample

\begin{tabular}{lccccc}
\hline & \multicolumn{3}{c}{ Summary statistics } & \multicolumn{2}{c}{$\begin{array}{c}\text { Difference in annualized return } \\
\text { on investment (in \%) }\end{array}$} \\
\cline { 2 - 6 } & Mean & Median & $\begin{array}{c}\text { Standard } \\
\text { deviation }\end{array}$ & $\begin{array}{c}\text { Mean - Actual } \\
\text { repurchases mean }\end{array}$ & $t$-test \\
\hline Actual repurchases & -0.805 & 0.343 & 23.564 & & \\
Repurchase average - 1 year & -1.059 & 0.904 & 23.035 & -0.254 & -0.75 \\
Repurchase average - 2 years & 0.542 & 2.603 & 22.775 & 1.348 & 2.65 \\
Repurchase average - 3 years & 2.782 & 4.234 & 22.071 & 3.587 & 5.64 \\
Repurchase average - 4 years & 2.072 & 3.420 & 22.753 & 2.877 & 4.72 \\
Sample lifetime & 4.244 & 5.395 & 21.517 & 5.050 & 7.10 \\
\hline
\end{tabular}




\section{Table 6: Robustness of return on repurchase investment}

This table examines the robustness of difference in means tests on the annualized rate of return (in \%) on actual repurchase investments versus "smoothed" repurchases. Panel A includes the 2,898 firms with repurchases between 2001 and 2010, the time period after the adoption of SEC Rule 10b5-1. Panel B (Panel C) includes the sample of open repurchase announcements between 1984 and 2010 that were at least $90 \%$ (less than 25\%) completed within 3 or 4 years (as indicated). Panel D incorporates the full sample of firms with sufficient repurchase and returns data (5,248 firms), but assumes that firms repurchase at the minimum quarterly closing price. Panel $\mathrm{E}$ lists the difference in returns by stated motive. A firm enters the stated motive category if it announced a repurchase with the listed stated motive any time during our sample period. Smoothed repurchases are generated by averaging actual repurchases over one-, two-, three-, or four-year periods, or the entire sample life of the firm, as indicated, in Panels A, D, and E, and over the period corresponding to the completion rate period in Panels B and C. Appendix A provides a full description of our returns measures.

Panel A: Implementation of smoothed strategy: The post-Rule 10b5-1 period

\begin{tabular}{lccccc}
\hline & \multicolumn{3}{c}{ Summary statistics } & $\begin{array}{c}\text { Difference in annualized return } \\
\text { on investment (in \%) }\end{array}$ \\
\cline { 2 - 6 } & Mean & Median & $\begin{array}{c}\text { Standard } \\
\text { deviation }\end{array}$ & $\begin{array}{c}\text { Mean - Actual } \\
\text { repurchases mean }\end{array}$ & $t$-test \\
\hline Actual repurchases & 7.018 & 4.114 & 55.955 & & 2.36 \\
Repurchase average - 1 year & 7.462 & 4.334 & 56.060 & 0.444 & 7.00 \\
Repurchase average - 2 years & 8.595 & 5.438 & 56.295 & 1.576 & 10.53 \\
Repurchase average - 3 years & 9.534 & 6.356 & 56.163 & 2.516 & 9.33 \\
Repurchase average - 4 years & 9.283 & 5.978 & 56.309 & 2.265 & 12.23 \\
Sample lifetime & 10.134 & 7.083 & 56.178 & 3.116 & \\
\hline
\end{tabular}

Panel B: Completed repurchase plans

\begin{tabular}{|c|c|c|c|c|c|c|}
\hline \multirow[b]{2}{*}{$\begin{array}{l}\text { Completion } \\
\text { Window }\end{array}$} & & \multicolumn{3}{|c|}{ Summary statistics } & \multicolumn{2}{|c|}{$\begin{array}{c}\text { Difference in annualized return on } \\
\text { investment (in \%) }\end{array}$} \\
\hline & & Mean & Median & $\begin{array}{l}\text { Standard } \\
\text { deviation }\end{array}$ & $\begin{array}{c}\text { Mean - Actual } \\
\text { repurchases mean }\end{array}$ & $t$-test \\
\hline \multirow{2}{*}{$\begin{array}{c}3 \text { Years } \\
(\# \text { Obs }=6,708)\end{array}$} & Actual & 10.131 & 7.032 & 38.381 & & \\
\hline & Smoothed & 10.924 & 8.495 & 36.754 & 0.793 & 4.66 \\
\hline \multirow{2}{*}{$\begin{array}{c}4 \text { Years } \\
(\# \text { Obs }=7,226)\end{array}$} & Actual & 8.604 & 6.651 & 34.904 & & \\
\hline & Smoothed & 9.691 & 7.941 & 33.142 & 1.087 & 7.35 \\
\hline
\end{tabular}

\section{Panel C: Low completion rate plans}

\begin{tabular}{|c|c|c|c|c|c|c|}
\hline \multirow[b]{2}{*}{$\begin{array}{l}\text { Completion } \\
\text { Window }\end{array}$} & & \multicolumn{3}{|c|}{ Summary statistics } & \multicolumn{2}{|c|}{$\begin{array}{l}\text { Difference in annualized return on } \\
\text { investment (in \%) }\end{array}$} \\
\hline & & Mean & Median & $\begin{array}{l}\text { Standard } \\
\text { deviation }\end{array}$ & $\begin{array}{l}\text { Mean - Actual } \\
\text { repurchases mean }\end{array}$ & $t$-test \\
\hline \multirow{2}{*}{$\begin{array}{c}3 \text { Years } \\
(\# \text { Obs }=4,876)\end{array}$} & Actual & 13.849 & 6.215 & 91.588 & & \\
\hline & Smoothed & 15.705 & 8.784 & 90.898 & 1.856 & 6.60 \\
\hline \multirow{2}{*}{$\begin{array}{c}4 \text { Years } \\
(\# \text { Obs }=4,819)\end{array}$} & Actual & 11.896 & 5.298 & 90.892 & & \\
\hline & Smoothed & 13.668 & 7.622 & 90.229 & 1.773 & 6.73 \\
\hline
\end{tabular}




\begin{tabular}{lccccc}
\hline & \multicolumn{3}{c}{ Summary statistics } & \multicolumn{2}{c}{$\begin{array}{c}\text { Difference in annualized return } \\
\text { on investment (in \%) }\end{array}$} \\
\cline { 2 - 6 } & Mean & Median & $\begin{array}{c}\text { Standard } \\
\text { deviation }\end{array}$ & $\begin{array}{c}\text { Mean - Actual } \\
\text { repurchases mean }\end{array}$ & $t$-test \\
\hline Actual repurchases & 17.624 & 9.282 & 65.637 & & \\
Repurchase average - 1 year & 19.831 & 9.669 & 70.951 & 2.206 & 8.93 \\
Repurchase average - 2 years & 21.417 & 10.383 & 71.949 & 3.793 & 13.53 \\
Repurchase average - 3 years & 22.167 & 11.234 & 71.636 & 4.543 & 15.39 \\
Repurchase average - 4 years & 22.172 & 11.301 & 72.332 & 4.548 & 14.67 \\
Sample lifetime & 23.175 & 12.515 & 71.564 & 5.550 & 17.91 \\
\hline
\end{tabular}

\section{Panel E: Stated motivations}

\begin{tabular}{lcccccccc}
\hline & \multicolumn{2}{c}{$\begin{array}{c}\text { Undervaluation } \\
\text { Stated motivation }\end{array}$} & \multicolumn{2}{c}{$\begin{array}{c}\text { ESOP } \\
\text { (\# Obs =872) }\end{array}$} & \multicolumn{2}{c}{ EPS } & \multicolumn{2}{c}{$\begin{array}{c}\text { Acquisition } \\
\text { (\# Obs = 146) }\end{array}$} \\
\hline & Diff & $t$-stat & Diff & $t$-stat & Diff & $t$-stat & Diff & $t$-stat \\
Repurchase average - 1 year & -0.151 & -1.83 & -0.478 & -1.50 & -0.092 & -0.45 & -0.413 & -0.84 \\
Repurchase average - 2 years & 0.507 & 1.13 & -0.155 & -0.38 & 0.392 & 1.01 & 0.191 & 0.30 \\
Repurchase average - 3 years & 1.026 & 2.50 & 0.423 & 1.40 & 1.540 & 2.70 & 1.101 & 1.52 \\
Repurchase average - 4 years & 1.237 & 3.08 & 0.585 & 1.82 & 1.365 & 2.35 & 0.413 & 0.64 \\
Sample lifetime & 2.395 & 5.69 & 1.760 & 4.30 & 2.230 & 2.79 & 1.548 & 1.85 \\
\hline
\end{tabular}




\section{Table 7: Market timing regressions}

This table presents a pooled OLS regression of the factors associated with repurchase timing for firms in our sample between 1984 and 2010. The dependent variable is Repurchase Value, the difference between actual returns to repurchasing and the returns if those repurchasing dollars had been smoothed over 4 years. Earnings Management 1: Analysts is a dummy variable equaling one if the company met or beat the mean analyst forecast but would have missed it in the absence of the repurchase. The without-repurchase EPS is calculated using the 'As-If I' EPS measure of Cheng, Harford, and Zheng (2015) and is compared to the IBES mean analyst estimate to identify firms that would have missed earnings estimates. Earnings Management 2: Dilution is an indicator variable equaling one when the firm repurchased in one or more quarters during the year and the number of shares outstanding would have increased in the absence of the repurchase. Institutional Ownership \% measures the percentage of shares owned by institutional investors. Institutional Exit represents the percent of quarters within the event window where the firm has significant repurchase activity (repurchases greater than $1 \%$ of common shares outstanding) as well as significant declines in institutional ownership (decreases in institutional ownership of greater than $1 \%$ of common shares outstanding). Lost Blockholder equals one if the firm lost a blockholder over the event window window. Blockholders are shareholders owning more than $5 \%$ of a firm who have filed form $13 \mathrm{G}$ with the SEC. High Entrenchment Index is an indicator equal to one if the E Index is greater than or equal to 4 (out of 6). Overconfidence is an indicator variable if the CEO buys firm stock in his or her own account during the event window. Motivations (Earnings per Share (EPS), Employee Stock Options (ESOP), Undervaluation $(U V)$, and Acquisition $(A C Q)$ ). are identified using the "purpose codes" from the SDC Repurchases database and are linked based on whether the motivation was announced during the event window. The following lagged firm controls are included but not reported for succinctness: Cap Ex is capital expenditures, scaled by total assets, Cash is cash and cash equivalents, scaled by total assets, Cash Flow is the sum of income before extraordinary items and depreciation and amortization, scaled by total assets, Firm Size is the natural log of the market capitalization of the firm (number of shares outstanding times share price), Leverage is total liabilities, scaled by total assets, Dividends is an indicator variable equal to one if the firm paid a dividend in the prior year, $R \& D$ is research and development expense, scaled by total assets, $B / M$, measured at the end of the prior quarter, is the book value of common equity divided by market capitalization, and Negative B/M dummy equals one if $\mathrm{B} / \mathrm{M}$ is negative. Cap Ex, Cash, Firm Size, Leverage, $R \& D$, and Cash Flow are measured at the end of the prior quarter and are winsorized at the $1^{\text {st }}$ and $99^{\text {th }}$ percentile. Industry fixed effects and year dummies are included in all regressions. Standard errors are robust and adjusted for clustering at the firm level. $t$-statistics are presented below coefficients in parentheses, and $* * *$, and $* * *$ represent statistical significance at the 10,5 , and 1 percent level. 
Table 7: Market timing regressions, continued

\section{Dependent Variable: 4 Year Repurchase Value}

\begin{tabular}{|c|c|c|c|c|c|c|}
\hline Earnings Mgmt 1: Analysts & $\begin{array}{r}-1.896 * * * \\
(-3.396)\end{array}$ & $\begin{array}{r}-1.577 * * \\
(-2.474)\end{array}$ & $\begin{array}{r}-1.558 * * \\
(-2.442)\end{array}$ & $\begin{array}{r}-1.532 * * \\
(-2.372)\end{array}$ & & \\
\hline Earnings Mgmt 2: Dilution & $\begin{array}{r}-9.273 * * * \\
(-4.254)\end{array}$ & $\begin{array}{r}-9.519 * * * \\
(-3.679)\end{array}$ & $\begin{array}{r}-9.673 * * * \\
(-3.735)\end{array}$ & $\begin{array}{r}-9.686 * * * \\
(-3.747)\end{array}$ & & \\
\hline Inst. Ownership \% & $\begin{array}{r}2.568 * * \\
(2.280)\end{array}$ & $\begin{array}{r}1.804 \\
(1.291)\end{array}$ & $\begin{array}{r}1.315 \\
(0.947)\end{array}$ & $\begin{array}{r}1.329 \\
(0.956)\end{array}$ & & \\
\hline Lost Blockholder & & $\begin{array}{r}0.262 \\
(0.320)\end{array}$ & $\begin{array}{r}0.200 \\
(0.244)\end{array}$ & $\begin{array}{r}0.203 \\
(0.248)\end{array}$ & & \\
\hline Institutional Exit & & $\begin{array}{r}0.179 \\
(0.226)\end{array}$ & $\begin{array}{r}0.127 \\
(0.160)\end{array}$ & $\begin{array}{r}0.128 \\
(0.161)\end{array}$ & & \\
\hline Lost Block* Inst Exit & & $\begin{array}{c}-1.814^{*} \\
(-1.802)\end{array}$ & $\begin{array}{l}-1.771^{*} \\
(-1.758)\end{array}$ & $\begin{array}{c}-1.770 * \\
(-1.758)\end{array}$ & & \\
\hline High Entrenchment Index & & & $\begin{array}{r}-1.777 * * * \\
(-2.671)\end{array}$ & $\begin{array}{r}-1.768 * * * \\
(-2.652)\end{array}$ & $\begin{array}{r}-1.664 * * * \\
(-2.917)\end{array}$ & $\begin{array}{r}-1.407 * * * \\
(-3.604)\end{array}$ \\
\hline Overconfidence & & & & $\begin{array}{r}-0.283 \\
(-0.384)\end{array}$ & & \\
\hline Motivation: EPS & & & & & $\begin{array}{r}-1.818 \\
(-1.565)\end{array}$ & $\begin{array}{r}-2.978 * * * \\
(-2.792)\end{array}$ \\
\hline Motivation: ESOP & & & & & $\begin{array}{r}-0.579 \\
(-0.618)\end{array}$ & $\begin{array}{r}-0.041 \\
(-0.052)\end{array}$ \\
\hline Motivation: UV & & & & & $\begin{array}{r}-1.275^{* *} \\
(-1.979)\end{array}$ & $\begin{array}{c}-1.127 * * \\
(-1.986)\end{array}$ \\
\hline Motivation: Acquisition & & & & & $\begin{array}{r}2.377 \\
(1.367)\end{array}$ & $\begin{array}{r}0.778 \\
(0.634)\end{array}$ \\
\hline Industry FE & Yes & Yes & Yes & Yes & Yes & Yes \\
\hline Year FE & Yes & Yes & Yes & Yes & Yes & Yes \\
\hline Lagged Firm Controls & Yes & Yes & Yes & Yes & Yes & No \\
\hline \# Obs & 6,253 & 4,223 & 4,223 & 4,223 & 6,253 & 11,809 \\
\hline Adj R2 & 0.032 & 0.032 & 0.034 & 0.033 & 0.030 & 0.019 \\
\hline
\end{tabular}




\section{Appendix A: Measuring the cost of repurchase-related financial flexibility}

This appendix illustrates the process by which we calculate our various measures of the cost of repurchase-related financial flexibility. The following procedure is executed for each firm in our sample.

\section{Rate of return on actual repurchases}

Let $R e p_{t}$ equal the dollar value of shares repurchased by the firm during quarter $t$ and let $r_{q}$ equal the rate of return on the firm's stock during quarter $q$. A firm remains in our sample for $N$ quarters. We consider each repurchase a quarterly investment, and therefore a cash outflow. We assume that repurchase dollars are invested at the end of each quarter and held until the end of quarter $N$, when the firm exits our sample. To calculate the annualized rate of return on repurchase investments, we solve for the annualized internal rate of return (IRR) of cash flows $\mathrm{CF}_{1}-\mathrm{CF}_{N}$ :

$$
\begin{gathered}
\text { Return on actual repurchases }=\operatorname{IRR}\left(C F_{1}, C F_{2}, \ldots, C F_{N}\right), \text { where } \\
C F_{1}=-\operatorname{Rep}_{1}, \\
C F_{2}=-\operatorname{Rep}_{2}, \\
\vdots \\
C F_{N-1}=-\operatorname{Rep}_{N-1}, \\
\text { and } \\
C F_{N}=-\operatorname{Rep}_{N}+\sum_{t=1}^{N}\left\{\operatorname{Rep}_{t} \times \prod_{q=t+1}^{N}\left(1+r_{q}\right)\right\} .
\end{gathered}
$$

\section{Rate of return on smoothed repurchases}

To calculate the rate of return on smoothed repurchases, our investment cash flows are now equal to a smoothed repurchase value instead of the actual repurchase value. Specifically, let $S_{t}$ be the smoothed repurchase value for quarter $t$. We define $S_{t}$ based on the length of the smoothing period. For 1-, 2-, 3-, and 4-year repurchase smoothing, we average repurchases over 4, 8, 12, and 16 quarters, respectively, beginning the quarter that the firm enters the sample. When repurchases are smoothed over the entire sample period, we simply average quarterly repurchases over the entire life of the firm.

In robustness checks, we also smooth repurchases forward in time. For 1-, 2-, 3-, and 4-year forward smoothing, we average repurchases over the prior 4, 8, 12, and 16 quarters, respectively. These calculations require that actual repurchases occur prior to or concurrent with our smoothed 
repurchase quarter. Table A.1 illustrates the calculation of smoothed quarterly repurchases over our varying time periods.

\section{Table A.1: Smoothed repurchase calculation}

This table illustrates the calculation of smoothed quarterly repurchases over our varying time periods. $\operatorname{Rep}_{t}$ equals the dollar value of shares repurchased during quarter $t$. $R$ equals the number of quarters in which the firms remains in our sample.

\begin{tabular}{lc}
\hline Smoothing time period & Quarterly smoothed repurchases $\left(S_{t}\right)$ \\
\hline $\begin{array}{l}1 \text { year } \\
\qquad \text { years }\end{array}$ & $S_{1}=S_{2}=S_{3}=S_{4}=\frac{1}{4} \sum_{t=1}^{4} \operatorname{Rep}_{t}$ \\
\hline & $S_{1}=\ldots=S_{8}=\frac{1}{8} \sum_{t=1}^{8} \operatorname{Rep}_{t}$ \\
\hline years & $S_{1}=\ldots=S_{12}=\frac{1}{12} \sum_{t=1}^{12} \operatorname{Rep}_{t}$ \\
\hline & $S_{1}=\ldots=S_{16}=\frac{1}{16} \sum_{t=1}^{16} \operatorname{Rep}_{t}$ \\
\hline
\end{tabular}

Evenly spaced

$$
S_{1}=\ldots=S_{R}=\frac{1}{R} \sum_{t=1}^{R} \operatorname{Rep}_{t}
$$

1 year forward

$$
S_{t}=\frac{1}{4} \sum_{q=t-3}^{t} \operatorname{Rep}_{q}
$$

$Y$ years forward

$$
S_{t}=\frac{1}{4 y} \sum_{q=t-4 y+1}^{t} \operatorname{Rep}_{q}
$$

The rate of return on smoothed repurchases equals the annualized internal rate of return (IRR) of cash flows $C F_{1}-C F_{N}$ : 
Return on smoothed repurchases $=\operatorname{IRR}\left(C F_{1}, C F_{2}, \ldots, C F_{N}\right)$, where

$$
\begin{gathered}
C F_{1}=-S_{1}, \\
C F_{2}=-S_{2}, \\
\vdots \\
C F_{N-1}=-S_{N-1}, \\
\text { and } \\
C F_{N}=-S_{N}+\sum_{t=1}^{N}\left\{S_{t} \times \prod_{q=t+1}^{N}\left(1+r_{q}\right)\right\} .
\end{gathered}
$$

\section{Market timing}

The dependent variable in Table 7 captures the ability of managers to time repurchases. Specifically, Repurchase Value is calculated as the difference in the annualized return on actual repurchases and smoothed repurchases:

Repurchase Value $_{t}=$ Return on actual repurchases - Return on smoothed repurchases . $_{\text {. }}$

However, we do not calculate the terminal value of smoothed repurchases at end of the full sample period as before. Rather, we calculate the terminal value at the end of each four year smoothing period. This method allows us to have multiple observations per firm. The table below presents summary statistics for the Table 7 variables, including the Repurchase Value, 4 Year measure. The mean and median are negative, implying poor long-run timing, but there is substantial variation.

Table A.2: Summary statistics for cross-sectional analysis

\begin{tabular}{lccccc}
\hline & $\#$ Obs & $25^{\text {th }} \%$ & Mean & Median & $75^{\text {th }} \%$ \\
\hline Repurchase Value & 6,310 & -5.949 & -0.073 & -0.124 & 4.606 \\
Firm Size (Ln) & 6,304 & 5.320 & 6.619 & 6.515 & 7.740 \\
Leverage, Book & 6,310 & 0.325 & 0.508 & 0.509 & 0.666 \\
Cash & 6,301 & 0.022 & 0.150 & 0.070 & 0.218 \\
Cash Flow & 6,310 & 0.013 & 0.025 & 0.025 & 0.038 \\
CapEx & 6,310 & 0.003 & 0.012 & 0.008 & 0.017 \\
R\&D & 6,310 & 0.000 & 0.007 & 0.000 & 0.007 \\
Dividend Payer & 6,310 & 0.000 & 0.608 & 1.000 & 1.000 \\
B/M & 6,294 & 0.288 & 0.530 & 0.462 & 0.688 \\
Negative B/M & 6,294 & 0.000 & 0.011 & 0.000 & 0.000 \\
Earning Mgmt 1 & 6,310 & 0.000 & 0.378 & 0.000 & 1.000 \\
Earnings Mgmt 2 & 6,310 & 0.000 & 0.038 & 0.000 & 0.063 \\
Inst. Ownership \% & 6,310 & 0.377 & 0.572 & 0.584 & 0.774 \\
Overconfidence & 6,310 & 0.000 & 0.179 & 0.000 & 0.000 \\
\hline
\end{tabular}




\section{Appendix B: Robustness tests}

\section{B.1 Robustness of returns of repurchase investments}

Table B.1 examines the return on repurchase investment results presented in Table 4. Panel A presents returns on actual and smoothed repurchase investments for 4,852 firms that did not announce a Dutch auction, tender offer, or accelerated share repurchase over the sample period. Our conclusions that (i) smoothing repurchases through time outperforms actual repurchases and (ii) the longer the smoothing period, the better the performance, continue to hold for this subsample.

Panel B excludes the financial crisis period (2008-2010) from returns calculations. Returns on repurchases smoothed over one year, our shortest smoothing period, are not statistically different from returns on actual repurchases. However, the difference in smoothed and actual repurchase returns increases in magnitude and statistical significance as we lengthen our smoothing period.

Panel $\mathrm{C}$ examines whether our results hold for the most liquid firms, defined as firms in the lowest Amihud (2002) illiquidity quintile. Illiquidity is defined as the average ratio of the daily absolute return to the dollar trading volume on the day calculated over the 250 trading days prior to the quarter that the firm enters our sample. We require at least 50 trading days to calculate illiquidity. In all but the one-year smoothing period, firms would have done significantly better by smoothing their repurchases through time.

Panel D calculates repurchases net of stock issuances. Specifically, the dollar value of repurchases is defined as the decrease in split-adjusted shares outstanding times the quarterly closing price. This measure essentially excludes repurchases that are offset by stock issuances. In all cases, returns to smoothed repurchases exceed returns to actual repurchases, with the difference being statistically different for 2-year smoothing and beyond. 


\section{B.2 Benchmark-adjusted return on repurchase investment}

Our "control firm" is the firm itself, over the same time period, with different assumptions on returns weighting (weighting by actual versus smoothed repurchases). Hence, benchmarkadjusting returns is only necessary in cases of dramatic and rapid changes in the risk profile of the firm or in the risk-premium. In Table B.2, we benchmark-adjust returns using the Fama-French 25 portfolios formed on size and book-to-market. Following the construction of the portfolios themselves, for each firm in our sample, we calculate size as the market capitalization in June of each year $t$ and book-to-market using book equity from fiscal year end $t-1$, divided by market capitalization for December of year $t-1$. Sample firms are matched with their size and book-tomarket benchmark portfolio in June of each year. The matching process results in the loss of several firms, implying that our base case differs slightly for firms with benchmark portfolios. In Panel A of Table B.2, we present our base results for the subsample of matched firms, which are almost identical to those presented in Panel A of Table 4 as expected.

Panel B presents returns to repurchases if the firm had invested repurchase dollars in the size and book-to-market benchmark portfolio instead of itself. Panel C presents differences between the investment in the firm and the benchmark. We see that the average repurchasing firm would be better off investing in the benchmark portfolio than itself: Investing the same dollar amount at the same time in the benchmark portfolio yields returns of 9.64 percent on average, 1.74 percent greater than the return the firm earned on its investment in itself. But the benefit to investing in the benchmark portfolio instead of the firm itself quickly dissipates when repurchase dollars are smoothed. There is no statistical difference in returns to repurchase dollars invested in the firm versus the same repurchase dollars invested in the benchmark when repurchase dollars are more evenly spaced through time. These results are consistent with firms choosing the wrong time to invest in themselves. 
Interestingly, even an investment in the benchmark portfolio can be improved by smoothing repurchase dollars over longer time periods. Long-term smoothing results in statistically significant improvements ranging from 0.43 percentage points for two-year smoothing to 1.26 percentage points for four-year smoothing. However, the improvement from smoothing repurchase investments in the firm significantly exceeds the benefits to smoothing repurchase investments in the benchmark portfolio over all smoothing periods.

\section{B.3 Return on repurchase investment by time in sample and size quintile}

When repurchases are smoothed across the entire life of the firm in the sample, a concern might be that our results are driven by actual repurchases that occurred long before or after the smoothing time period. Because firms can have very different lives in our sample, we repeat our analysis in Table 4 based on how long a firm is in our sample. The average (median) firm remains in our sample for almost 9 years (7 years), and, as shown in Panel A of Table B.3, the most common sample life is between 0 and 5 years, with about 44 percent of our sample firms falling into this group. We calculate the average difference in returns between the actual repurchase strategy and the smoothed strategy of spreading repurchases evenly over the sample life of the firm for each group. Regardless of length of time in our sample, the return difference is positive and significant, economically and statistically, but there is no obvious pattern. The biggest difference, 2.94 percent per year, occurs in the $0-5$ year group. The second largest, 1.96 percent per year, is for firms with more than 20 years in our sample.

In Panels B, C, and D we consider the impact of firm size, book-to-market ratios, and lagged returns on our results. Prior literature has found that small firms are able to time the market over short windows and that firms with high book-to-market ratios and low lagged returns are more likely to be undervalued. We divide our sample firms into quintiles based on when a firm 
enters our sample. Return differences are significantly positive, economically and statistically, for all size and book-to-market quintiles and for all but one lagged returns quintile.

Panel E separates the sample on cash quintiles. We find that cash on hand does not drive the results. Lastly, Panel F separates those firms which delist from those which remain in the sample. The first section calculates the returns to smoothing excluding firms which delist while the later section replicates the analysis using the subsample of firms which delist. The benefits to smoothing are consistent across both samples. 


\section{Table B.1: Robustness of return on repurchase investment}

This table examines the return on repurchase investment results presented in Table 4. Panel A excludes any firm that announced a Dutch auction, tender offer, or accelerated share repurchase over the sample period. This filter reduces our sample size to 4,852 firms. Panel B excludes quarters during the financial crisis (quarters in 2008-2010). Panel C uses only the most liquid firms, defined as firms in the lowest Amihud (2002) illiquidity quintile. Illiquidity is defined as the average ratio of the daily absolute return to the dollar trading volume on the day calculated over the 250 trading days prior to the quarter that the firm enters our sample. We require at least 50 trading days to calculate illiquidity. Panel D uses repurchases net of stock issuances. Specifically, the dollar value of repurchases is defined as the decrease in split-adjusted shares outstanding times the quarterly closing price. This measure essentially excludes repurchases that are offset by stock issuances.

Panel A: Exclude Dutch auctions, tender offers, and accelerated share repurchases

\begin{tabular}{lccccc}
\hline & \multicolumn{3}{c}{ Summary statistics } & \multicolumn{3}{c}{$\begin{array}{c}\text { Difference in annualized } \\
\text { return on investment (in \%) }\end{array}$} \\
\cline { 2 - 6 } & Mean & Median & $\begin{array}{c}\text { Standard } \\
\text { deviation }\end{array}$ & $\begin{array}{c}\text { Mean - Actual } \\
\text { repurchases mean }\end{array}$ & $t$-test \\
\hline Actual repurchases & 8.063 & 4.865 & 62.550 & & \\
Repurchase average - 1 year & 8.549 & 5.011 & 63.598 & 0.487 & 2.03 \\
Repurchase average - 2 years & 9.301 & 5.809 & 63.994 & 1.238 & 5.05 \\
Repurchase average - 3 years & 9.641 & 6.395 & 63.960 & 1.578 & 6.17 \\
Repurchase average - 4 years & 9.847 & 6.812 & 64.039 & 1.784 & 6.85 \\
Evenly spaced repurchases & 10.005 & 7.915 & 64.360 & 1.942 & 7.10 \\
\hline
\end{tabular}

Panel B: Exclude financial crisis period (2008-2010)

\begin{tabular}{lccccc}
\hline & \multicolumn{3}{c}{ Summary statistics } & \multicolumn{2}{c}{$\begin{array}{c}\text { Difference in annualized } \\
\text { return on investment (in \%) }\end{array}$} \\
\cline { 2 - 6 } & Mean & Median & $\begin{array}{c}\text { Standard } \\
\text { deviation }\end{array}$ & $\begin{array}{c}\text { Mean - Actual } \\
\text { repurchases mean }\end{array}$ & $t$-test \\
\hline Actual repurchases & 8.562 & 6.449 & 59.520 & & \\
Repurchase average - 1 year & 8.544 & 6.152 & 60.365 & -0.018 & -0.09 \\
Repurchase average - 2 years & 8.907 & 6.595 & 60.671 & 0.345 & 1.68 \\
Repurchase average - 3 years & 9.102 & 7.060 & 60.652 & 0.540 & 2.51 \\
Repurchase average - 4 years & 9.313 & 7.400 & 60.709 & 0.751 & 3.41 \\
Evenly spaced repurchases & 9.698 & 8.506 & 60.887 & 1.136 & 4.89 \\
\hline
\end{tabular}




\begin{tabular}{lccccc}
\hline & \multicolumn{3}{c}{ Summary statistics } & \multicolumn{3}{c}{$\begin{array}{c}\text { Difference in annualized } \\
\text { return on investment (in \%) }\end{array}$} \\
\cline { 2 - 6 } & Mean & Median & $\begin{array}{c}\text { Standard } \\
\text { deviation }\end{array}$ & $\begin{array}{c}\text { Mean - Actual } \\
\text { repurchases mean }\end{array}$ & $t$-test \\
\hline Actual repurchases & 12.179 & 7.235 & 57.346 & & \\
Repurchase average - 1 year & 12.918 & 7.603 & 60.417 & 0.739 & 1.07 \\
Repurchase average - 2 years & 13.782 & 8.311 & 60.601 & 1.603 & 2.21 \\
Repurchase average - 3 years & 14.309 & 8.816 & 60.477 & 2.130 & 2.89 \\
Repurchase average - 4 years & 14.564 & 8.786 & 60.386 & 2.385 & 3.22 \\
Evenly spaced repurchases & 15.030 & 9.974 & 60.550 & 2.851 & 3.76 \\
\hline
\end{tabular}

Panel D: Repurchase net of stock issues

\begin{tabular}{lccccc}
\hline & \multicolumn{3}{c}{ Summary statistics } & \multicolumn{3}{c}{$\begin{array}{c}\text { Difference in annualized } \\
\text { return on investment (in \%) }\end{array}$} \\
\cline { 2 - 6 } & Mean & Median & $\begin{array}{c}\text { Standard } \\
\text { deviation }\end{array}$ & $\begin{array}{c}\text { Mean - Actual } \\
\text { repurchases mean }\end{array}$ & $t$-test \\
\hline Actual repurchases & 8.344 & 5.869 & 58.501 & & \\
Repurchase average - 1 year & 8.599 & 6.176 & 61.988 & 0.255 & 0.75 \\
Repurchase average - 2 years & 8.837 & 6.691 & 58.782 & 0.492 & 2.28 \\
Repurchase average - 3 years & 9.131 & 7.130 & 58.585 & 0.787 & 3.37 \\
Repurchase average - 4 years & 9.309 & 7.368 & 58.696 & 0.965 & 4.09 \\
Sample lifetime & 9.234 & 8.164 & 59.002 & 0.889 & 3.50 \\
\hline
\end{tabular}




\section{Table B.2: Benchmark-adjusted return on repurchase investment}

This table reexamines the return on repurchase investment results presented in Table 4 using benchmarkadjusted returns. Panel A includes firms that can be merged with the Fama-French 25 portfolios on size and book-to-market. The matching process reduces our sample size to 5,103 firms. Panel B shows the return on repurchase investment, assuming that repurchase dollars were invested in the benchmark portfolio instead of the repurchasing firm. Panel $\mathrm{C}$ presents the difference in mean and difference-in-difference tests.

\section{Panel A: Base case for firms with benchmark}

\begin{tabular}{lccccc}
\hline & \multicolumn{3}{c}{ Summary statistics } & \multicolumn{2}{c}{$\begin{array}{c}\text { Difference in annualized return } \\
\text { on investment (in \%) }\end{array}$} \\
\cline { 2 - 6 } & Mean & Median & $\begin{array}{c}\text { Standard } \\
\text { deviation }\end{array}$ & $\begin{array}{c}\text { Mean - Actual } \\
\text { repurchases mean }\end{array}$ & $t$-test \\
\hline Actual repurchases & 7.901 & 5.228 & 59.874 & & \\
Repurchase average - 1 year & 8.328 & 5.293 & 60.803 & 0.426 & 2.16 \\
Repurchase average - 2 years & 9.005 & 6.109 & 61.169 & 1.104 & 5.13 \\
Repurchase average - 3 years & 9.389 & 6.645 & 61.111 & 1.488 & 6.55 \\
Repurchase average - 4 years & 9.548 & 7.082 & 61.215 & 1.647 & 7.11 \\
Sample lifetime & 9.757 & 8.151 & 61.519 & 1.856 & 7.58 \\
\hline
\end{tabular}

Panel B: Repurchase dollars invested in size and book-to-market benchmark portfolio

\begin{tabular}{lccccc}
\hline & \multicolumn{3}{c}{ Summary statistics } & \multicolumn{3}{c}{$\begin{array}{c}\text { Difference in annualized return } \\
\text { on investment (in \%) }\end{array}$} \\
\cline { 2 - 6 } & Mean & Median & $\begin{array}{c}\text { Standard } \\
\text { deviation }\end{array}$ & $\begin{array}{c}\text { Mean - Actual } \\
\text { repurchases mean }\end{array}$ & $t$-test \\
\hline Actual repurchases & 9.644 & 8.218 & 13.083 & & \\
Repurchase average - 1 year & 9.642 & 8.216 & 13.130 & -0.002 & -0.05 \\
Repurchase average - 2 years & 9.828 & 8.347 & 13.013 & 0.185 & 3.56 \\
Repurchase average - 3 years & 9.984 & 8.433 & 12.906 & 0.340 & 6.00 \\
Repurchase average - 4 years & 10.033 & 8.371 & 12.885 & 0.389 & 6.65 \\
Sample lifetime & 10.337 & 8.732 & 12.685 & 0.693 & 11.11 \\
\hline
\end{tabular}

Panel C: Differences and $t$-tests

\begin{tabular}{lcccc}
\hline & $\begin{array}{c}\text { Difference } \\
\text { in means }\end{array}$ & $t$-test & $\begin{array}{c}\text { Difference in } \\
\text { difference }\end{array}$ & $t$-test \\
\hline Actual repurchases & -1.743 & -2.16 & & \\
Repurchase average - 1 year & -1.314 & -1.60 & 0.429 & 2.29 \\
Repurchase average - 2 years & -0.823 & -0.99 & 0.920 & 4.56 \\
Repurchase average - 3 years & -0.595 & -0.72 & 1.148 & 5.38 \\
Repurchase average - 4 years & -0.485 & -0.58 & 1.258 & 5.78 \\
Sample lifetime & -0.580 & -0.69 & 1.163 & 5.02 \\
\hline
\end{tabular}


Table B.3: Return on repurchase investment: Subsample analysis

This table presents robustness tests from summary statistics and difference in means tests for the return on actual repurchases versus smoothed repurchases (Diff). Smoothed repurchases are generated by averaging actual repurchases over the entire sample period. Panel A segments the sample on the number of years that the firm has been in the sample. Panels B, C, and D segment on quintiles of market capitalization, book-tomarket ratio, and lagged market-adjusted returns, respectively, all calculated when the firm enters the sample. Panel E segments the sample on cash quintiles. Panel F segments the sample on delisting status.

Panel A: Time in sample

\begin{tabular}{lccccccccccc}
\hline & \multicolumn{2}{c}{$0-5$} & \multicolumn{2}{c}{$6-10$} & \multicolumn{2}{c}{$11-15$} & \multicolumn{2}{c}{$16-20$} & \multicolumn{2}{c}{$>20$} \\
Years in sample & (\# Obs = 2,301) & \multicolumn{2}{c}{ (\# Obs= 1,272) } & (\# Obs= 884) & (\# Obs= 341) & \multicolumn{2}{c}{ (\# Obs= 450) } \\
\hline & Diff & $t$-stat & Diff & $t$-stat & Diff & $t$-stat & Diff & $t$-stat & Diff & $t$-stat \\
Repurchase average - 1 year & 1.046 & 2.40 & -0.114 & -1.04 & -0.026 & -0.41 & 0.146 & 1.00 & -0.075 & -1.25 \\
Repurchase average - 2 years & 2.352 & 4.97 & 0.123 & 0.84 & 0.321 & 3.06 & 0.083 & 0.47 & 0.137 & 1.75 \\
Repurchase average - 3 years & 2.720 & 5.50 & 0.660 & 3.75 & 0.575 & 3.65 & 0.612 & 2.76 & 0.348 & 3.31 \\
Repurchase average - 4 years & 2.918 & 5.82 & 0.762 & 3.78 & 0.902 & 5.31 & 0.659 & 2.44 & 0.455 & 4.93 \\
Sample lifetime & 2.943 & 5.84 & 1.050 & 3.56 & 0.693 & 2.22 & 1.608 & 3.40 & 1.956 & 7.02 \\
\hline
\end{tabular}

Panel B: Firm size quintiles

\begin{tabular}{lccccccccccc}
\hline Size quintile & \multicolumn{1}{c}{1 (Small) } & \multicolumn{2}{c}{2} & \multicolumn{3}{c}{3} & \multicolumn{2}{c}{4} & \multicolumn{2}{c}{5 (Large) } \\
\hline & Diff & $t$-stat & Diff & $t$-stat & Diff & $t$-stat & Diff & $t$-stat & Diff & $t$-stat \\
Repurchase average - 1 year & 1.042 & 2.68 & 0.079 & 0.29 & 0.059 & 0.21 & 1.243 & 2.46 & -0.292 & -0.31 \\
Repurchase average - 2 years & 1.604 & 4.25 & 1.008 & 2.85 & 0.516 & 1.55 & 1.954 & 3.67 & 0.595 & 0.61 \\
Repurchase average - 3 years & 1.316 & 2.85 & 1.570 & 4.02 & 1.134 & 3.31 & 2.309 & 4.25 & 1.119 & 1.14 \\
Repurchase average - 4 years & 1.504 & 3.16 & 1.697 & 4.15 & 1.290 & 3.65 & 2.499 & 4.56 & 1.427 & 1.45 \\
Sample lifetime & 1.790 & 3.55 & 1.783 & 4.01 & 1.406 & 3.60 & 2.719 & 4.69 & 2.186 & 2.20 \\
\hline
\end{tabular}

Panel C: Book-to-market quintiles

\begin{tabular}{lccccccccccc}
\hline Book-to-market quintile & \multicolumn{1}{c}{ 1 (Growth) } & \multicolumn{2}{c}{2} & \multicolumn{3}{c}{3} & \multicolumn{3}{c}{4} & \multicolumn{2}{c}{ (Value) } \\
\hline & Diff & $t$-stat & Diff & $t$-stat & Diff & $t$-stat & Diff & $t$-stat & Diff & $t$-stat \\
Repurchase average - 1 year & 0.490 & 0.76 & 0.325 & 0.96 & -0.054 & -0.20 & 0.601 & 1.76 & 0.977 & 2.11 \\
Repurchase average - 2 years & 1.479 & 2.11 & 1.101 & 2.96 & 0.501 & 1.57 & 1.269 & 3.19 & 1.422 & 3.22 \\
Repurchase average - 3 years & 1.917 & 2.70 & 1.507 & 3.73 & 0.919 & 2.51 & 1.772 & 4.16 & 1.506 & 3.17 \\
Repurchase average - 4 years & 2.033 & 2.82 & 1.722 & 4.18 & 1.047 & 2.75 & 2.004 & 4.60 & 1.727 & 3.52 \\
Sample lifetime & 2.363 & 3.18 & 1.924 & 4.32 & 1.428 & 3.49 & 2.225 & 4.73 & 1.683 & 3.14 \\
\hline
\end{tabular}


Table B.3: Continued

Panel D: Lagged returns quintiles

\begin{tabular}{lccccccccccc}
\hline Lagged return quintile & \multicolumn{2}{c}{1 (Low) } & \multicolumn{2}{c}{2} & \multicolumn{2}{c}{3} & \multicolumn{2}{c}{4} & \multicolumn{2}{c}{ (High) } \\
\hline & Diff & $t$-stat & Diff & $t$-stat & Diff & $t$-stat & Diff & $t$-stat & Diff & $t$-stat \\
Repurchase average - 1 year & 0.624 & 1.81 & 0.926 & 2.51 & 0.621 & 1.76 & -0.856 & -1.22 & 0.541 & 1.30 \\
Repurchase average - 2 years & 1.631 & 4.02 & 1.434 & 3.54 & 1.392 & 3.38 & -0.241 & -0.33 & 1.033 & 2.43 \\
Repurchase average - 3 years & 1.997 & 4.54 & 1.754 & 3.97 & 1.968 & 4.55 & 0.288 & 0.39 & 1.209 & 2.68 \\
Repurchase average - 4 years & 2.194 & 4.85 & 1.811 & 4.04 & 2.191 & 4.86 & 0.563 & 0.76 & 1.378 & 2.99 \\
Sample lifetime & 2.357 & 4.90 & 1.954 & 4.09 & 2.343 & 4.87 & 0.932 & 1.21 & 1.803 & 3.63 \\
\hline
\end{tabular}

\section{Panel E: Cash quintiles}

\begin{tabular}{lcccccccccccc}
\hline Cash quintile & \multicolumn{2}{c}{1 (Small) } & \multicolumn{2}{c}{2} & \multicolumn{3}{c}{3} & \multicolumn{3}{c}{4} & \multicolumn{2}{c}{5 (Large) } \\
\hline & Diff & $t$-stat & Diff & $t$-stat & Diff & $t$-stat & Diff & $t$-stat & Diff & $t$-stat \\
Repurchase average - 1 year & 1.024 & 2.58 & 0.618 & 1.98 & 0.471 & 1.44 & 0.381 & 1.14 & -0.028 & -0.05 \\
Repurchase average - 2 years & 1.809 & 3.82 & 0.886 & 3.22 & 1.322 & 3.34 & 1.258 & 2.97 & 0.708 & 1.29 \\
Repurchase average - 3 years & 1.849 & 3.43 & 1.326 & 4.10 & 1.920 & 4.56 & 1.757 & 3.91 & 1.062 & 1.90 \\
Repurchase average - 4 years & 2.199 & 3.98 & 1.525 & 4.52 & 2.083 & 4.74 & 1.980 & 4.28 & 1.112 & 1.97 \\
Sample lifetime & 2.160 & 3.74 & 1.834 & 4.79 & 2.483 & 5.38 & 2.228 & 4.43 & 1.351 & 2.29 \\
\hline
\end{tabular}

Panel F: Delisting status

\begin{tabular}{lcccc}
\hline & \multicolumn{2}{c}{$\begin{array}{c}\text { Excluding Delisted Firms } \\
(\# \text { Obs = 2,099) }\end{array}$} & \multicolumn{2}{c}{$\begin{array}{c}\text { Delisted Firms Only } \\
(\# \text { Obs= 3,149) }\end{array}$} \\
\hline & Diff & $t$-stat & Diff & $t$-stat \\
Repurchase average - 1 year & 0.660 & 5.07 & 0.277 & 0.89 \\
Repurchase average - 2 years & 1.720 & 8.85 & 0.740 & 2.25 \\
Repurchase average - 3 years & 2.458 & 11.28 & 0.893 & 2.60 \\
Repurchase average - 4 years & 2.765 & 12.26 & 0.987 & 2.83 \\
Sample lifetime & 3.954 & 16.63 & 0.587 & 1.59 \\
\hline
\end{tabular}

